\title{
DAMPAK PENGGANDA INDUSTRI PEMBIBITAN GERAKAN NASIONAL REHABILITASI HUTAN DAN LAHAN ${ }^{1)}$ (Multiplier Effect of Seedling Industry of National Movement on Forest and Land Rehabilitation)
}

\author{
Oleh / By : \\ Satria Astana, Deden Djaenudin, Lukas Rumpoko Wibowo, \\ Lasmanto Gatot Haryono, Nunung Parlinah \& Indartik ${ }^{2)}$
}

\begin{abstract}
One of the government efforts to overcome the problems of forest damage and critical land is to implement the national program, namely Gerakan Nasional Rehabilitasi Hutan dan Lahan (Gerhan) (National Movement on Forest and Land Rehabilitation). As a whole, the impact of Gerhan is expected to be able to change the social behavior of the society toward the development of national consciousness to plant tree. However, the trend of this behavior cannot be predicted since the social, environmental and economic impacts of Gerhan are notyet exactly described. Ideally, these three impacts need to be studied simultaneously. This research, however, is virtually more focused on the economic impacts, especially the multiplier effects of seedling industry of Gerhan, which aims at studying the multiplier effects with respect to output, income and employment. The research was conducted in three sample villages involved in Gerban program: Desa Sirnajaya, Garut District, West Java; Desa Margomulyo, Wonogiri District, Central Java; and Desa Golo, Bojonegoro District, East Java. By using I-O model, the result of research reveals that the multiplier effects of seedling industry of Gerhan in the economy of each sample village was small. This suggests that the Gerhan policy needs to be improved especially related to the importance of using the local resources such as compost and the establishment of own seed in each Gerhan village.
\end{abstract}

Keywords: Seedling industry, multiplier effect, economy, village, I-O model.

\begin{abstract}
ABSTRAK
Salah satu upaya pemerintah mengatasi kerusakan hutan dan lahan kritis adalah melaksanakan program Gerakan Nasional Rehabilitasi Hutan dan Lahan (Gerhan). Secara keseluruhan dampak Gerhan diharapkan dapat menimbulkan perubahan perilaku sosial masyarakat menuju terbangunnya kesadaran nasional untuk menanam pohon. Namun kecenderungan demikian tidak dapat diramalkan selama dampak sosial, dampak lingkungan dan dampak ekonominya tidak diketahui dengan pasti. Idealnya ketiga dampak tersebut perlu dikaji secara simultan. Namun penelitian ini lebih memfokuskan pada dampak ekonomi khususnya dampak pengganda industri pembibitan Gerhan, yang bertujuan untuk mengkaji dampak pengganda terkait dengan output, pendapatan dan tenaga kerja. Penelitian dilaksanakan di tiga desa contoh yang terlibat dalam program Gerhan: Desa Sirnajaya, Kabupaten Garut, Jawa Barat; Desa Margomulyo, Kabupaten Wonogiri, Jawa Tengah; dan Desa Golo, Kabupaten Bojonegoro, Jawa Timur. Dengan menggunakan model I-O, hasil penelitian menunjukkan bahwa dampak pengganda industri pembibitan Gerhan dalam perekonomian masing-masing desa contoh adalah kecil. Hal ini menyarankan bahwa kebijakan Gerhan perlu diperbaiki terutama terkait dengan pentingnya menggunakan sumberdaya lokal seperti pupuk kandang dan pembangunan benih sendiri di masing-masing desa yang akan melaksanakan Gerhan.
\end{abstract}

Kata kunci: Industri pembibitan, dampak pengganda, perekonomian, desa, model I-O.

\footnotetext{
${ }^{1)}$ Naskah diterima tanggal 31 Oktober 2006 dan koreksi akhir tanggal 27 Maret 2007

${ }^{2)}$ Peneliti pada Puslitsosek, alamat Jl. Gunung Batu 5 Bogor
} 


\section{PENDAHULUAN}

Kerusakan hutan dan lahan kritis telah mencapai tingkat yang sangat memprihatinkan. Ini ditunjukkan oleh semakin meningkatnya frekuensi banjir dan tanah longsor setiap tahun di hampir seluruh wilayah Indonesia dalam skala yang besar. Menyadari dampak negatifnya terhadap kehidupan masyarakat yang begitu besar, pemerintah sedang berusaha dengan berbagai upaya untuk mengatasi permasalahannya. Salah satunya pemerintah melaksanakan program Gerakan Nasional Rehabilitasi Hutan dan Lahan (GNRHL atau Gerhan). Tujuan rehabilitasi hutan dan lahan adalah: (1) meningkatkan produktivitas lahan, (2) memperbaiki lingkungan, dan (3) meningkatkan kesejahteraan masyarakat khususnya masyarakat pedesaan. Sedangkan program Gerhan dapat berdampak ganda: (1) membangkitkan kesadaran masyarakat luas untuk menaman pohon, dan (2) menimbulkan efek berantai (multiplier effect) dalam perekonomian, terutama perekonomian pedesaan. Dalam krisis ekonomi yang belum pulih, Gerhan diharapkan dapat mendorong bangkitnya perekonomian, terutama sektor-sektor yang terkait baik ke belakang maupun ke depan.

Mengingat pentingnya arti Gerhan, Presiden RI kemudian mencanangkan Gerakan Nasional Rehabilitasi Hutan dan Lahan (Gerhan) sebagai gerakan moral secara nasional untuk menanam pohon di setiap kawasan hutan dan lahan kritis, sebagai wujud komitmen bangsa untuk meningkatkan kualitas lingkungan dan kelestarian hutan, dan kesejahteraan rakyat. Pencanangan sebagai gerakan moral nasional dilakukan pada tanggal 21 Januari 2004 di Desa Karang Duwet, Kecamatan Paliyan, Kabupaten Gunung Kidul, Provinsi Daerah Istimewa Yogyakarta. Untuk mengingat kejadiannya, Presiden RI juga menetapkan tanggal 21 Januari sebagai Hari Tanam Pohon Nasional. Target yang akan dicapai dalam Gerhan adalah merehabilitasi hutan dan lahan seluas 3 juta hektar, baik di dalam kawasan hutan maupun di luar kawasan hutan, yang diselesaikan dalam waktu 5 tahun. Program Gerhan dimulai pada tahun 2003 dengan target penanaman pohon seluas 300000 ha, di 29 DAS, meliputi 15 Propinsi, dan tersebar di 145 Kabupaten/Kota.

Untuk tahun 2004, rencana Gerhan akan merehabilitasi hutan dan lahan kritis seluas 500.000 ha, yang tersebar di 68 DAS prioritas I dan II, dan meliputi 27 propinsi, 242 kabupaten/kota. Kawasan hutan yang akan direhabilitasi seluas 350.000 ha, terdiri atas hutan konversi seluas 38.228 ha, hutan lindung seluas 93.163 ha, dan hutan produksi seluas 218.609 ha. Sedangkan target di luar kawasan hutan seluas 150.000 ha. Selanjutnya pelaksanaan program Gerhan dalam merehabilitasi hutan dan lahan kritis akan terus ditingkatkan, yaitu pada tahun 2005 seluas 600.000 ha, tahun 2006 seluas 700.000 ha, dan tahun 2007 seluas 900.000 ha. Sehingga secara akumulatif dalam waktu 5 tahun akan dapat merehabilitasi hutan dan lahan kritis seluas 3 juta ha. Sampai lima tahun ke depan program Gerhan akan difasilitasi oleh pemerintah. Namun karena keterbatasan dana pemerintah, selanjutnya masyarakat dan pihak swasta, diharapkan secara sukarela dan swadana bersedia melakukan rehabilitasi hutan dan lahan di daerah masing-masing.

Realisasi kegiatan Gerhan pada tahun 2003 mencapai 60 - 70\% dari luas yang ditargetkan sebesar 300.000 ha di 29 DAS yang meliputi 15 propinsi dan tersebar di 145 kabupaten/kota. Target kegiatan Gerhan tahun 2004 yang meliputi 350.000 ha di dalam kawasan hutan, dan 150.000 ha di luar kawasan hutan, memerlukan bibit sebanyak 600 juta bibit seharga Rp 750 miliar, sedangkan total dana yang dibutuhkan sebesar Rp 2.2 triliun. Program Gerhan dibagi ke dalam dua kegiatan, yaitu: (1) kegiatan pokok, dan (2) kegiatan 
penunjang (Menko Kesra/Ketua TKPLRRN, 2003). Kegiatan pokok dibedakan ke dalam dua kegiatan, yaitu: (1) pencegahan perusakan lingkungan (PPL), dan (2) kegiatan penanaman dan konservasi tanah (PKT). Kegiatan PPL terdiri atas: (1) sosialisasi pencegahan perusakan lingkungan, (2) pemberdayaan masyarakat, dan (3) penegakan hukum. Sedangkan kegiatan PKT terdiri atas: (1) pembibitan, (2) pembuatan tanaman, dan (3) konservasi tanah. Kegiatan penunjang antara lain terdiri atas: (1) penyediaan baseline data waduk, dam, sungai dan danau, dan (2) asistensi teknik dalam teknologi persemaian dan penafsiran citra satelit.

Secara keseluruhan dampak Gerhan diharapkan dapat menimbulkan perubahan perilaku sosial masyarakat menuju terbangunnya kesadaran nasional untuk menanam pohon. Sehingga upaya merehabilitasi hutan dan lahan lambat laun dapat berjalan secara nasional dan alamiah. Namun demikian, kecenderungan demikian belum dapat diramalkan dengan baik selama dampak sosial, dampak lingkungan dan dampak ekonominya tidak diketahui dengan pasti. Idealnya ketiga dampak tersebut perlu dikaji secara simultan. Namun demikian, kajian ini lebih difokuskan pada multiplier effect Gerhan.

Permasalahan yang dikaji dibatasi yaitu apakah Gerhan khususnya industri atau sektor pembibitan dalam kegiatan pokok PKT berdampak signifikan terhadap perekonomian pedesaan? Jika benar, apakah dampaknya tergolong relatif lebih tinggi dibandingkan dengan dampak kegiatan sektor-sektor lain? Jika tidak benar, mengapa atau apa saja faktor-faktor yang menyebabkan? Secara umum penelitian bertujuan untuk mengkaji dampak Gerhan khususnya industri atau sektor pembibitan dalam kegiatan PKT terhadap perekonomian pedesaan. Secara khusus penelitian bertujuan untuk mengkaji multiplier effect output, pendapatan dan tenaga kerja Gerhan khususnya industri atau sektor pembibitan dalam kegiatan PKT serta keterkaitan ke depan dan ke belakangnya serta daya penyebaran dalam perekonomian pedesaan. Hasil penelitian diharapkan dapat berguna sebagai bahan masukan untuk evaluasi kebijakan dalam meningkatkan peranan Gerhan khususnya kegiatan PKT dalam perekonomian pedesaan.

\section{METODOLOGI PENELITIAN}

\section{A. Kerangka Analisis}

Gerhan dapat dipandang sebagai bentuk aktivitas ekonomi (Gambar 1). Tiap bentuk kegiatan ekonomi dicirikan oleh adanya kebutuhan atas input, proses pengolahan input, dan output untuk konsumsi sendiri, dijual ke industri lain dan/atau ke konsumen akhir (Gambar 2). Sebagai kegiatan ekonomi, kegiatan Gerhan khususnya kegiatan PKT (Lampiran 1) dapat didisagregasi ke dalam sektor-sektor (Gambar 3), yang selanjutnya akan berdampak terhadap perekonomian secara keseluruhan. Dengan pemikiran demikian, kegiatan PKT dapat dijadikan salah satu sektor dalam sebuah perekonomian, termasuk perekonomian pedesaan (Gambar 4). Pada dasarnya sebuah perekonomian termasuk perekonomian pedesaan dapat digambarkan dalam bentuk Tabel Transaksi Input-Output sebagaimana Gambar 5. Pada Gambar 5 terlihat, tabel transaksi input-output memiliki empat kuadran.

Kuadran I, berisi sektor produktif atau yang melakukan proses produksi dan karenanya, kuadran ini dikenal dengan processing quadrant. Kuandran I menunjukkan aliran transaksi (penjualan atau pembelian) antar sektor yang dianalisis, dan bertindak sebagai inti analisis dari Model Iuput-Output. Kuadran II menunjukkan penjualan oleh masing-masing sektor ke permintaan akhir (final demand). Kuadran II biasanya memasukkan kolom yang berkaitan 
dengan konsumsi rumah tangga (bousehold consumption) (C), pembentukan kapital (investasi) (capital formation) (I), pengeluaran pemerintah (government expenditure) $(\mathrm{G})$, dan ekspor (export) (E). Kuadran III berisi input primer (primary inputs) untuk masing-masing industri, yaitu input yang tidak dibeli oleh industri dari sektor industri lokal. Komponen utamanya terdiri dari: upah dan gaji pekerja, gross operating surplus (depresiasi, laba tak terbagikan, dll), dan impor. Kuadran IV, menunjukkan input primer yang diserap oleh permintaan akhir. Dalam analisis input-output, Kuadran IV biasanya kurang dipertimbangkan dan sering diabaikan.

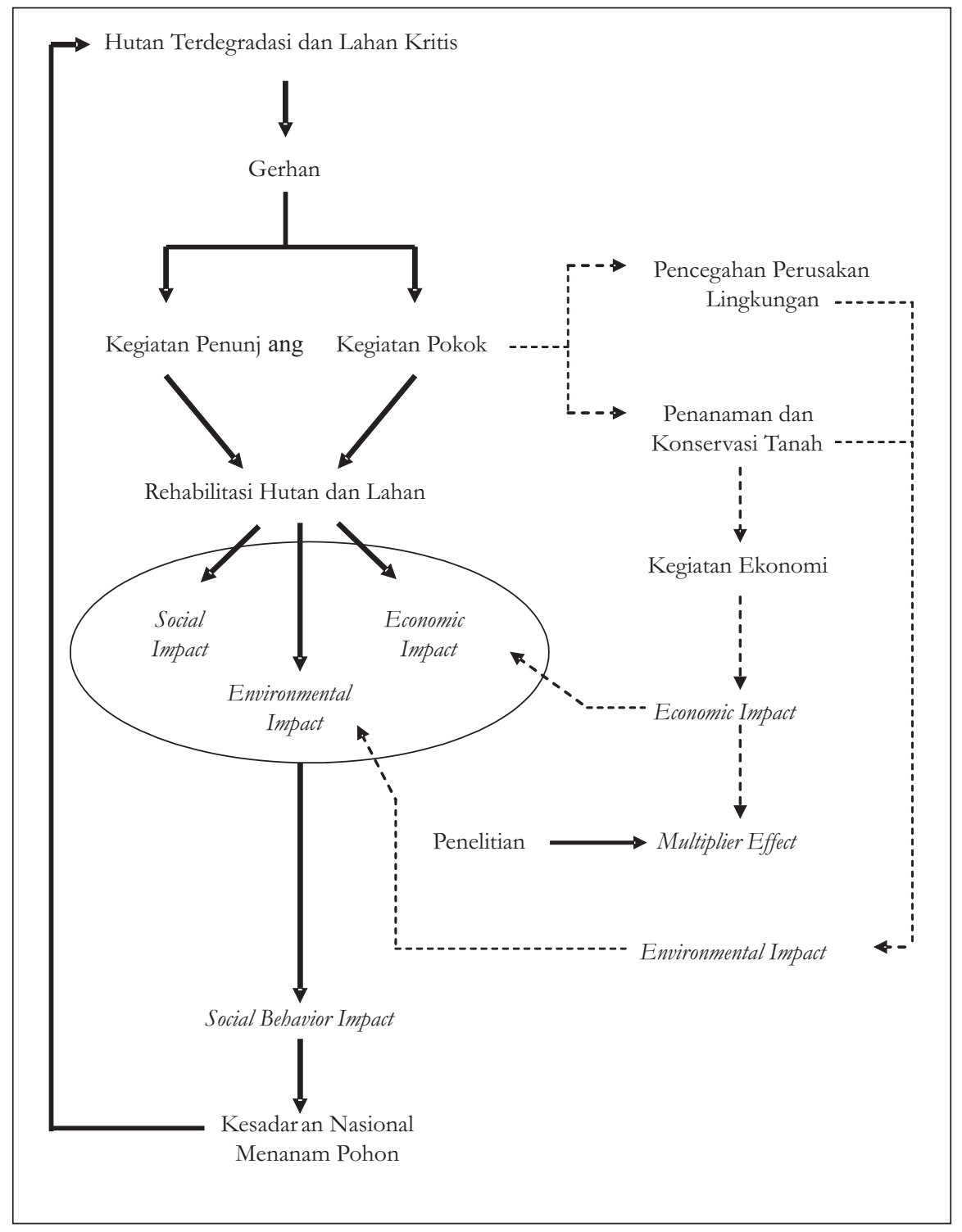

Gambar 1. Dampak Gerhan terhadap Perilaku Sosial Masyarakat 


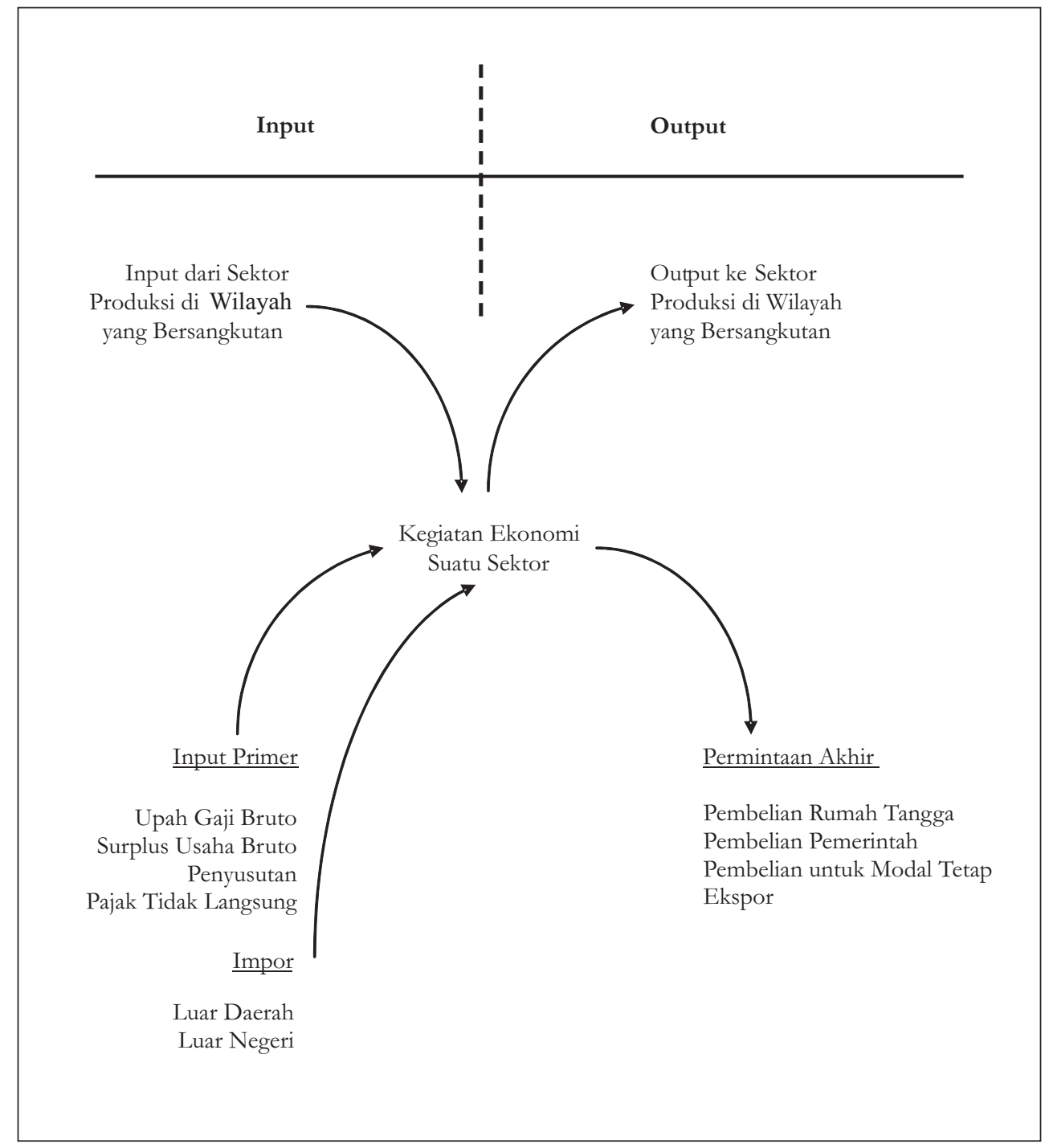

Gambar 2. Kegiatan Ekonomi Suatu Sektor dalam Perekonomian 


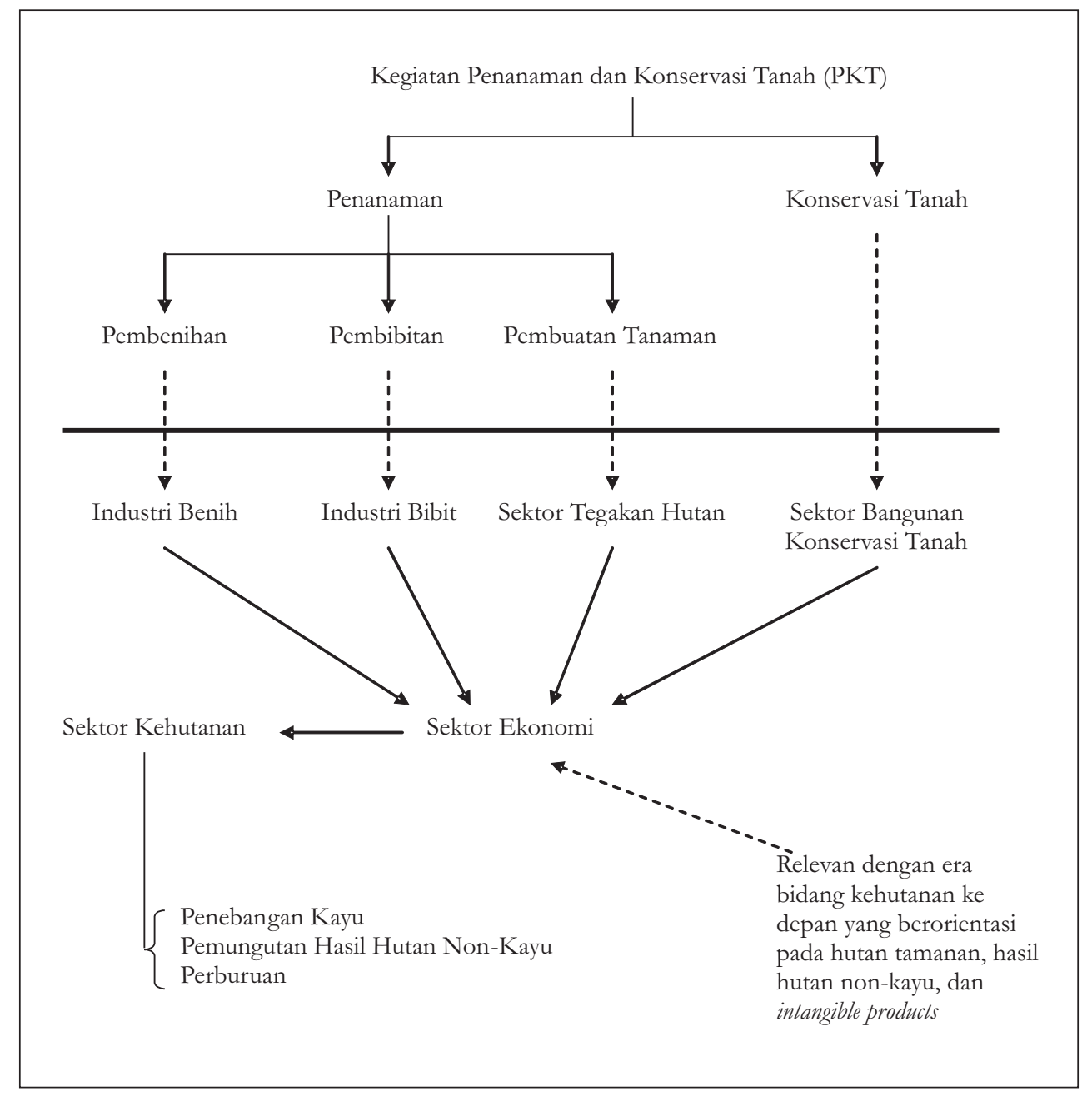

Gambar 3. Disagregasi Kegiatan PKT ke dalam Sektor Ekonomi 


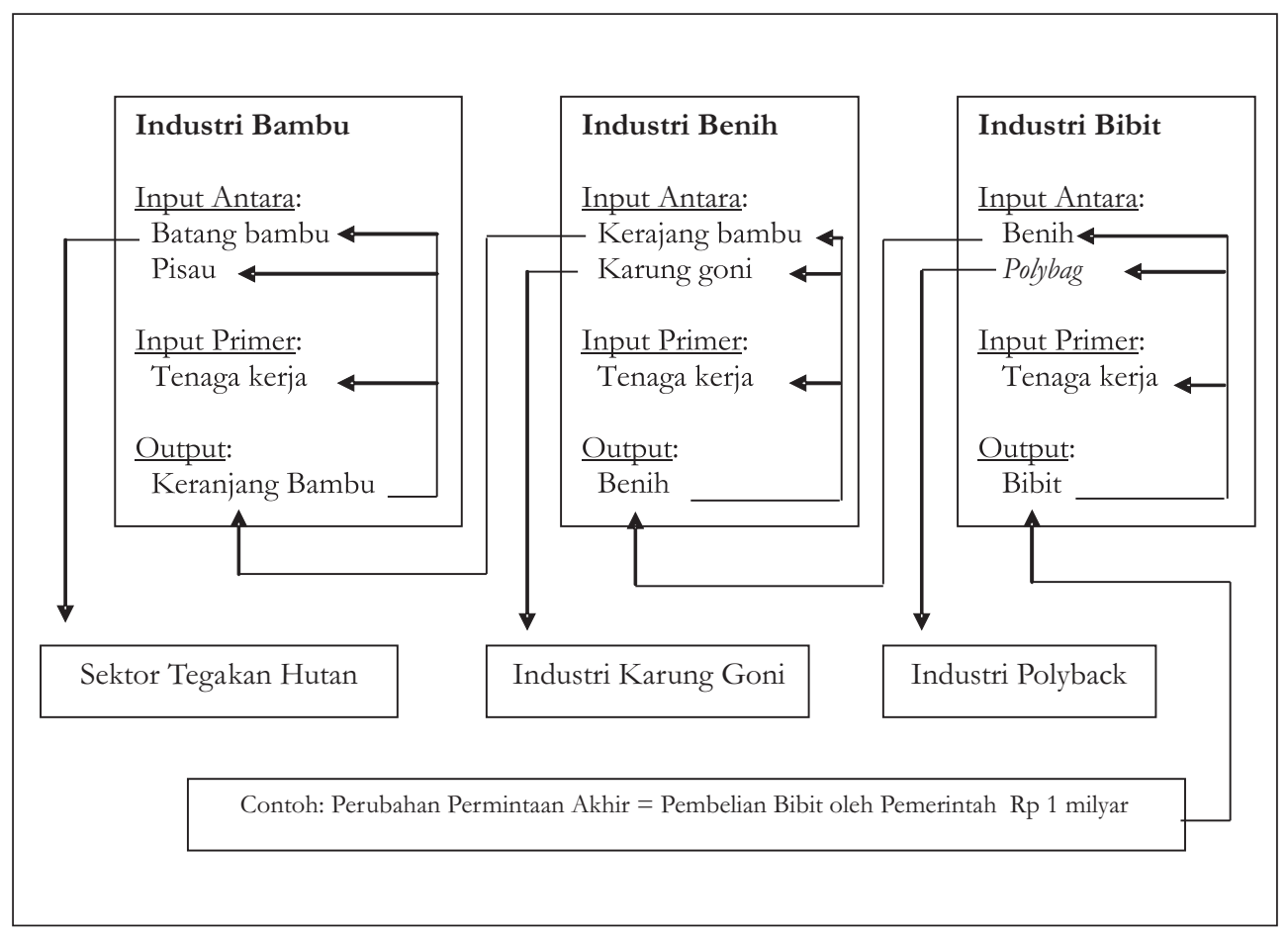

Gambar 4. Model Sederhana Keterkaitan antar Sektor Produksi dalam Perekonomian 


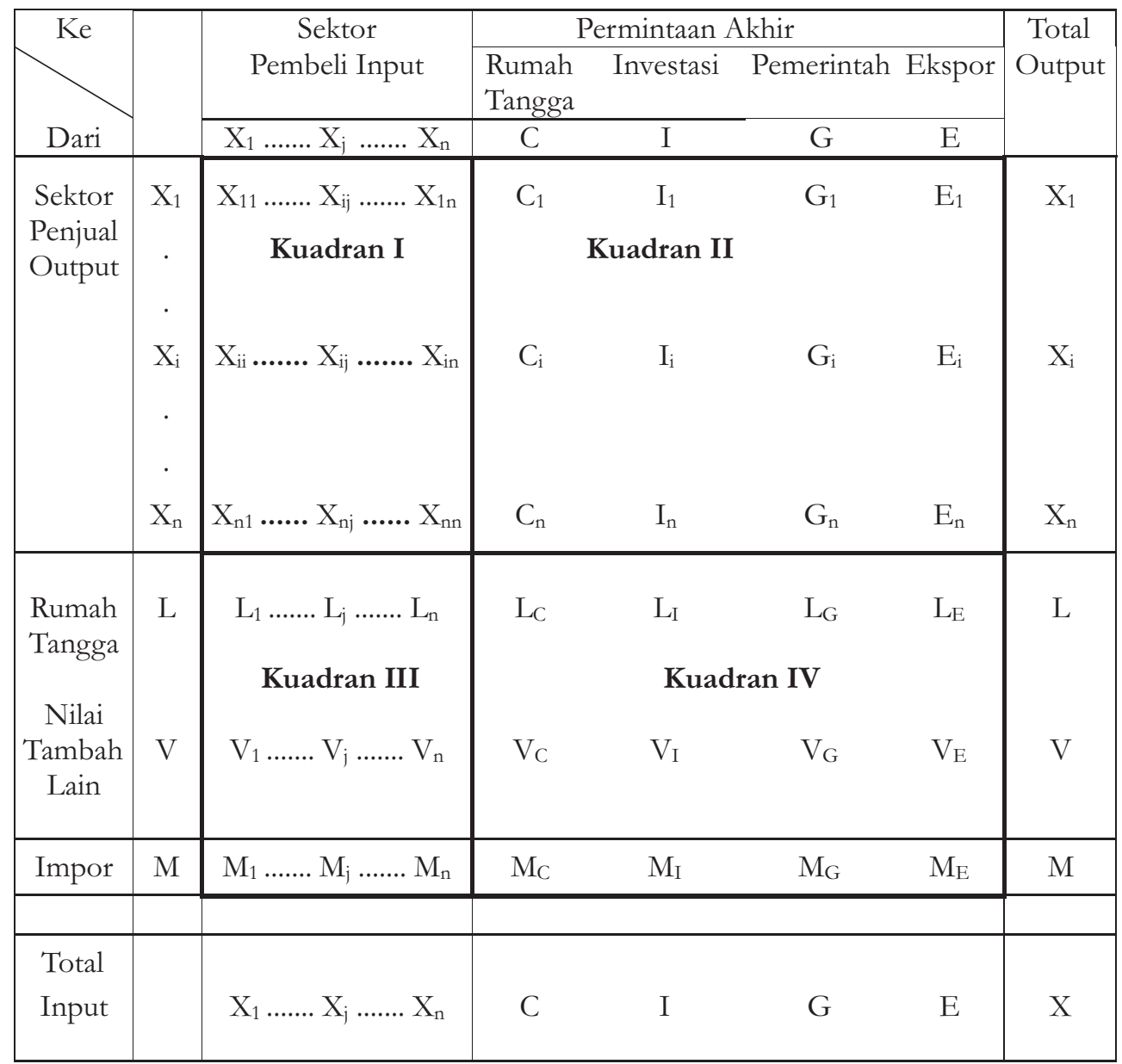

Gambar 5. Tabel Transaksi Input-Output dalam Suatu Perekonomian

Analisis Input-Output membutuhkan asumsi koefisien input yang konstan. Dengan demikian, jika terdapat input yang ditambahkan ke dalam proses produksi, maka output yang dihasilkan akan bertambah secara proporsional. Dengan kata lain, output merupakan fungsi linier homogen dari input. Walaupun asumsi yang demikian tergolong kaku, Darusman (1989) menyatakan bahwa asumsi tersebut dapat dipegang untuk analisis jangka pendek, terlebih hanya mengkaji perekonomian tertentu saja. Terdapat beberapa alasan kenapa asumsi yang demikian kaku dapat dipertahankan. Pertama, adanya kestabilan adat istiadat, serta perilaku dan sifat inertia di dalam masyarakat yang cenderung lebih menyenangi kemapanan. Kedua, kenyataan menunjukkan bahwa setiap perubahan atau inovasi baru memerlukan waktu yang lama dan biaya investasi yang besar (Darusman, 1989). Untuk analisis jangka panjang asumsi linieritas dapat diperlonggar dengan meramalkan perubahanperubahan yang terjadi dan hasil peramalannya dimasukkan ke dalam model Input-Output yang statis. Namun penelitian lebih menekankan pada analisis jangka pendek. 
Peranan sektor PKT dalam pembentukan output, nilai tambah bruto, permintaan antara dan permintaan akhir dapat diketahui secara langsung dari tabel transaksi I-O. Sedangkan untuk mengetahui peranan sektor PKT baik sebagai sektor penyedia input maupun sebagai sektor pemakai input serta dampak yang ditimbulkan sektor PKT terhadap perekonomian pedesaan dapat dikaji berdasarkan analisis pengganda (multiplier) dan keterkaitan (linkages). Menurut Richardson (1972), terdapat tiga jenis pengganda (multiplier) yang paling sering digunakan, yaitu: (1) pengganda output (output multiplier), (2) pengganda pendapatan (income multiplier), dan pengganda tenaga kerja (employment multiplier). Sedangkan keterkaitan, Daryanto (1995) menemukan 14 macam keterkaitan yang pernah digunakan. Namun keterkaitan yang umum digunakan ada enam macam, yaitu: (1) keterkaitan langsung ke belakang (direct backward linkage), (2) keterkaitan langsung ke depan (direct forward lingkage), (3) keterkaitan langsung dan tidak langsung ke belakang (direct and indirect backward lingkeages), (4) keterkaitan langsung dan tidak langsung ke depan (direct and indirect forward lingkages), (5) daya tarik atau daya penyebaran (power of dispersion), dan (6) daya dorong atau kepekaan penyebaran (sensitivity of dispersion).

\section{B. Penurunan Model Input-Output}

Persamaan dasar yang digunakan adalah :

$$
\begin{aligned}
& \mathrm{x}_{11}+\mathrm{x}_{12}+\ldots+\mathrm{x}_{1 \mathrm{n}}+\mathrm{Y}_{1}=\mathrm{X}_{1} \\
& \mathrm{x}_{21}+\mathrm{x}_{22}+\ldots+\mathrm{x}_{2 \mathrm{n}}+\mathrm{Y}_{2}=\mathrm{X}_{2} \\
& \text {. . . . } \\
& \mathrm{x}_{\mathrm{n} 1}+\mathrm{x}_{\mathrm{n} 2}+\ldots+\mathrm{x}_{\mathrm{nn}}+\mathrm{Y}_{\mathrm{n}}=\mathrm{X}_{\mathrm{n}}
\end{aligned}
$$

Jika diketahui matrik koefisien input:

$$
a_{i j} \frac{x_{i j}}{X_{j}}
$$

dan jika persamaan (2) disubstitusikan ke persamaan (1) maka didapat persamaan (3) sebagai berikut:

$$
\begin{aligned}
& a_{11} X_{1}+a_{12} X_{2}+\ldots+a_{1 n} X_{n}+Y_{1}=X_{1} \\
& a_{21} X_{1}+a_{22} X_{2}+\ldots+a_{2 n} X_{n}+Y_{2}=X_{2} \\
& \text {. } \text {. } . \\
& \mathrm{a}_{\mathrm{n} 1} \dot{\mathrm{X}}_{1}+\mathrm{a}_{\mathrm{n} 2} \dot{\mathrm{X}}_{2}+\ldots+\mathrm{a}_{\mathrm{nn}} \dot{\mathrm{X}}_{\mathrm{n}}+\dot{\mathrm{Y}}_{\mathrm{n}}=\dot{\mathrm{X}}_{\mathrm{n}}
\end{aligned}
$$

Kemudian jika ditulis dalam bentuk persamaan matrik, maka persamaan (3) akan menjadi persamaan berikut:

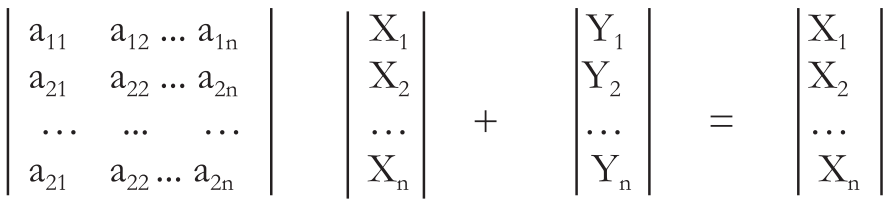

$$
\begin{aligned}
& \text { A } \mathrm{X}+\mathrm{Y}=\mathrm{X}
\end{aligned}
$$




$$
\mathrm{AX}+\mathrm{Y}=\mathrm{X} \text { atau }(\mathrm{I}-\mathrm{A}) \mathrm{X}=\mathrm{Y} \text { atau } \mathrm{X}=(\mathrm{I}-\mathrm{A})^{-1} \mathrm{Y}
$$

dimana:

$$
\begin{array}{ll}
\mathrm{I} & =\text { matrik identitas } \\
\mathrm{Y} & =\text { permintaan akhir } \\
\mathrm{X} & =\text { jumlah output } \\
(\mathrm{I}-\mathrm{A}) & =\text { matriks Leontief terbuka } \\
(\mathrm{I}-\mathrm{A})^{-1} & =\text { matriks kebalikan Leontief terbuka }
\end{array}
$$

Dari persamaan (4) terlihat bahwa output setiap sektor memiliki hubungan fungsional terhadap permintaan akhir, dengan ( I - A $)^{-1}$ sebagai koefisien antara. Jika matriks A memasukkan sektor rumah tangga, maka terbentuk matriks Leontief tertutup (A*). Matrik kebalikan tersebut mempunyai peranan penting sebagai alat analisis ekonomi karena menunjukkan adanya saling keterkaitan antara tingkat permintaan akhir dan tingkat produksi.

\section{Dampak Pengganda (Multiplier Effect)}

\begin{tabular}{|c|c|c|c|}
\hline \multirow[b]{2}{*}{ Nilai } & \multicolumn{3}{|c|}{ Dampak Pengganda (Multiplier Effect) } \\
\hline & $\begin{array}{l}\text { Output } \\
\text { (Rp) }\end{array}$ & $\begin{array}{c}\text { Pendapatan } \\
\text { (Income) } \\
\text { (Rp) } \\
\end{array}$ & $\begin{array}{c}\text { Tenaga Kerja } \\
\text { (Employment) } \\
\text { (Orang) }\end{array}$ \\
\hline Dampak awal & 1 & $\mathrm{~h}_{\mathrm{J}}$ & $\mathrm{e}_{\mathrm{J}}$ \\
\hline Dampak Putaran Pertama & $\mathrm{i}_{\mathrm{ij}}$ & $\mathrm{i}_{\mathrm{ij}} \mathrm{h}_{\mathrm{i}}$ & $\mathrm{i}_{\mathrm{ij}} \mathrm{e}_{\mathrm{i}}$ \\
\hline Dampak Dukungan Industri & ${ }_{i} \alpha_{i j}-1-{ }_{i} a_{i j}$ & ${ }_{i} \alpha_{i j} h_{i^{-}} h_{J^{-}} \quad{ }_{i} a_{i j} h_{i}$ & ${ }_{i} \alpha_{i j} e_{i j}-e_{J}-{ }_{i} a_{i j} e$ \\
\hline Dampak Induksi Konsumsi & ${ }_{i} \alpha^{*}{ }_{i j}-{ }_{i} \alpha_{i j}$ & ${ }_{i} \alpha^{*}{ }_{i j} h_{i^{-}} \quad{ }_{i} \alpha_{i j} h_{i}$ & ${ }_{i} \alpha^{*}{ }_{i j} e_{i}-{ }_{i} \alpha_{i j} e_{i}$ \\
\hline Dampak Total & ${ }_{i} \alpha^{*}$ & ${ }_{\mathrm{i}} \alpha^{*}{ }_{\mathrm{ij}} \mathrm{h}_{\mathrm{i}}$ & ${ }_{\mathrm{i}} \alpha^{*}{ }_{\mathrm{ij}} \mathrm{e}_{\mathrm{i}}$ \\
\hline Dampak Lanjutan & ${ }_{i} \alpha^{* i j}-1$ & ${ }_{i} \alpha^{*}{ }_{i j} h_{i}-h_{i}$ & ${ }_{i} \alpha^{*}{ }_{\mathrm{ij}} \mathrm{e}_{\mathrm{i}}-\mathrm{e}_{\mathrm{i}}$ \\
\hline
\end{tabular}

Berdasarkan matrik kebalikan Leontief, baik untuk model terbuka $\left({ }_{\mathrm{ij}}\right)$ (diturunkan dari matriks Leontief terbuka) maupun untuk model tertutup $\left({ }_{\mathrm{i} i}^{*}\right)$ (diturunkan dari matriks Leontief tertutup) dapat ditentukan nilai-nilai koefisien dampak pengganda output, pendapatan dan tenaga kerja, berdasarkan rumus yang tercantum pada Tabel 1 .

Tabel 1. Dampak Pengganda Output, Pendapatan dan Tenaga Kerja

Sumber (Source): Daryanto, A. 1990

Keterangan (Remark): $\mathrm{a}_{\mathrm{ij}}$ : koefisien output (output coefficient); hi : koefisien pendapatan rumah tangga (bousehold income coefficient); $\mathrm{e}_{\mathrm{i}}$ : koefisien tenaga kerja (employment coefficient); ij : matrik kebalikan Leontief terbuka (open Leontief inverse matrix); ${ }_{\mathrm{ij}}$ : matrik kebalikan Leontief tertutup (cloded Leontief inverse matrix). 
Sedangkan untuk melihat hubungan antara dampak awal dan dampak berikutnya per unit pengukuran dari sisi output, pendapatan dan tenaga kerja, dapat dihitung dengan menggunakan rumus pengganda Tipe I (diturunkan dari matriks Leontief terbuka) dan Tipe II (diturunkan dari matriks Leontieftertutup) sebagai berikut:

$$
\text { Tipe } \mathrm{I}=\frac{\text { Dampak Awal }+ \text { Dampak Putaran Pertama }+ \text { Dampak Dukungan Industri }}{\text { Dampak Awal }}
$$

Tipe II $=\frac{\text { Dampak Awal }+ \text { Dampak Putaran Pertama }+ \text { Dampak Dukungan Industri }+ \text { Dampak Industri Konsumsi }}{\text { Dampak Awal }}$

\section{Keterkaitan Langsung ke Depan dan ke Belakang}

Keterkaitan langsung ke depan menunjukkan pengaruh perubahan output suatu sektor tertentu akibat perubahan per unit permintaan akhir terhadap sektor-sektor yang menggunakan sebagian output sektor yang bersangkutan secara langsung. Keterkaitan ke depan muncul karena adanya supply input dengan asumsi supply menciptakan demandnya sendiri. Menurut Darusman (1989), asumsi demikian penting dikedepankan karena output suatu industri tidak begitu saja dapat menciptakan industri lanjutan karena masih memerlukan input-input lain. Adanya output suatu industri baru merupakan syarat perlu (necessary condition) dan belum merupakan syarat cukup (sufficient condition) bagi munculnya industri lanjutan yang memanfaatkan output tersebut. Keterkaitan langsung ke depan akan semakin rendah bila output sektor yang bersangkutan didistribusikan langsung ke konsumen atau diekspor ke luar daerah tanpa pengolahan terlebih dahulu (Darusman, 1989). Keterkaitan langsung ke depan dirumuskan sebagai berikut:

$$
\mathrm{KD}_{\mathrm{i}}={ }_{j 1}^{n} a_{i j}
$$

dimana :

$$
\begin{aligned}
& \mathrm{KD}=\text { keterkaitan langsung ke depan } \\
& \mathrm{a}_{\mathrm{ij}}=\text { unsur matrik koefisien teknis }
\end{aligned}
$$

Sedangkan keterkaitan langsung ke belakang menunjukkan pengaruh perubahan output suatu sektor tertentu akibat per unit perubahan permintaan akhir terhadap sektor-sektor yang menyediakan input antara bagi sektor yang bersangkutan secara langsung. Kaitan ke belakang muncul karena adanya permintaan input. Bila sumber-sumber dan teknologi yang dipergunakan diperoleh dari produksi setempat atau lokal, maka pengaruhnya akan maksimal, dan sebaliknya, bila dari impor, maka pengaruhnya akan minimal karena bocor ke luar daerah. Karenanya untuk mengukur keterkaitan ke belakang input impor perlu dikeluarkan (Darusman, 1989). Keterkaitan langsung ke belakang dirumuskan sebagai berikut :

$$
\mathrm{KBi}={ }_{i=1}^{n} a_{i j}
$$

dimana:

$$
\begin{aligned}
& \mathrm{KBi}=\text { keterkaitan langsung ke belakang } \\
& \mathrm{a}_{\mathrm{ij}}=\text { unsur matrik koefisien teknis }
\end{aligned}
$$




\section{E. Keterkaitan Langsung dan Tidak Langsung}

Keterkaitan langsung dan tidak langsung ke depan menunjukkan pengaruh perubahan output suatu sektor tertentu akibat perubahan per unit permintaan akhir terhadap sektorsektor yang menggunakan output sektor yang bersangkutan baik secara langsung maupun tidak langsung.

$$
\text { KDLTi }={ }_{j 1}^{n} \alpha_{i j}
$$

dimana:

$$
\begin{aligned}
& \text { KDLTi }=\text { keterkaitan langsung dan tidak langsung ke depan sektor i } \\
& \alpha_{\mathrm{ij}} \quad=\text { unsur matriks kebalikan Leontiefterbuka }
\end{aligned}
$$

Keterkaitan langsung dan tidak langsung ke belakang menunjukkan pengaruh perubahan output suatu sektor tertentu akibat perubahan per unit permintaan akhir terhadap sektor-sektor yang menyediakan input antara bagi sektor yang bersangkutan baik secara langsung maupun tidak langsung.

dimana:

$\mathrm{KBLTi}=$<smiles>[GeH2]=[GeH2]</smiles>

$$
\begin{aligned}
& \text { KBLTi }=\text { keterkaitan langsung dan tidak langsung ke belakang sektor } \mathrm{i} \\
& \alpha_{\mathrm{ij}} \quad=\text { unsur matriks kebalikan Leontief terbuka }
\end{aligned}
$$

\section{F. Dampak Penyebaran}

Keterkaitan langsung dan tidak langsung baik ke depan maupun ke belakang belum memadai dipakai sebagai landasan pemilihan sektor kunci. Sebab, mungkin saja suatu sektor yang pengaruh keterkaitannya lemah namun mempunyai pangsa yang besar terhadap produksi total (Darusman, 1989). Ukuran yang membobotkan kedua pertimbangan tersebut dikenal sebagai dampak penyebaran suatu sektor. Dampak penyebaran dibedakan ke dalam dua macam, yaitu: (1) daya tarik atau daya penyebaran (power of dispersion), yang diperoleh dari hasil pembobotan nilai keterkaitan ke belakang, dan (2) daya dorong atau kepekaan penyebaran (sensitivity of dispersion), yang diperoleh dari hasil pembobotan keterkaitan ke depan. Jenis pembobotan ada tiga jenis, yaitu: (a) jumlah sektor (n), (2) jumlah total matriks Leontieftertutup, dan (3) rataan semua unsur matriks Leontieftertutup (Darusman, 1989).

Konsep daya tarik berguna untuk mengetahui distribusi manfaat dari pengembangan suatu sektor terhadap perkembangan sektor-sektor lain melalui mekanisme transaksi pasar input. Konsep daya tarik juga sering diartikan sebagai kemampuan suatu sektor untuk meningkatkan pertumbuhan industri hulu. Suatu sektor tertentu (j) dikatakan mempunyai rangsangan yang tinggi terhadap sektor lain bila memiliki nilai daya tarik $\left(\mathrm{Pd}_{\mathrm{i}}\right)$ lebih besar dari satu, dan sebaliknya, mempunyai rangsangan rendah bila nilai daya tariknya $\left(\operatorname{Pd}_{j}\right)$ lebih kecil dari satu. Daya tarik suatu sektor $j$ dihitung dengan rumus sebagai berikut: 


$$
\begin{gathered}
\operatorname{Pd}_{j}=\frac{n{ }_{i 1}^{n} \alpha_{i j}}{n{ }^{n} \alpha_{i j}} \\
\text { dimana: } \\
i 1 j 1
\end{gathered}
$$

$$
\begin{aligned}
& \operatorname{Pd}_{\mathrm{j}}=\text { daya tarik atau daya penyebaran sektor } \mathrm{j} \\
& \alpha_{\mathrm{ij}}=\text { unsur matrik kebalikan Leontief terbuka }
\end{aligned}
$$

Sedangkan konsep daya dorong bermanfaat untuk mengetahui tingkat kepekaan suatu sektor terhadap sektor-sektor lain melalui mekanisme pasar output. Konsep daya dorong sering juga diartikan sebagai kemampuan suatu sektor tertentu untuk mendorong pertumbuhan produksi sektor-sektor lain yang memakai input sektor yang bersangkutan. Suatu sektor (i) dikatakan mempunyai rangsangan yang tinggi terhadap sektor lain bila nilai daya dorongnya $\left(\mathrm{Sd}_{\mathrm{i}}\right)$ lebih besar dari satu, dan sebaliknya, memiliki rangsangan yang rendah bila nilai daya dorongnya $\left(\mathrm{Sd}_{\mathrm{i}}\right)$ kurang dari satu. Daya dorong suatu sektor i dihitung dengan rumus :

dimana:

$$
\mathrm{Sd}_{\mathrm{i}}=\frac{n_{j 1}^{n} \alpha_{i j}}{n{ }^{n} \alpha_{i j}}
$$

$$
\begin{aligned}
& \mathrm{Sd}_{\mathrm{i}}=\text { daya dorong atau kepekaan penyebaran sektor } \mathrm{i} \\
& \alpha_{\mathrm{ij}}=\text { unsur matrik kebalikan Leontief terbuka }
\end{aligned}
$$

\section{G. Lokasi Penelitian}

Penelitian dilaksanakan di 3 desa yang terdapat program Gerhan, yaitu: Desa Golo, Kabupaten Bojonegoro, Jawa Timur; Desa Margomulyo, Kabupaten Wonogiri, Jawa Tengah; dan Desa Sirnajaya, Kabupaten Garut, Jawa Barat. Kecuali Kabupaten Garut, pemilihan kabupaten contoh didasarkan pada realisasi pelaksanaan Gerhan terluas (Lampiran 1). Pemilihan beberapa lokasi penelitian bukan dimaksudkan untuk membandingkan peranan sektor PKT di suatu daerah pedesaan tertentu lebih penting dari daerah pedesaan yang lain, melainkan peranan relatif sektor PKT terhadap sektor lain di daerah pedesaan masingmasing. Pembandingan dampak ekonomi suatu sektor antar daerah yang berbeda dapat misleading disebabkan oleh perbedaan nilai input dan output antar daerah yang dibandingkan (Cox dan Munn, 2001). Dalam penelitian ini, multiplier effect sektor kehutanan yang dihitung pada tingkat desa.

\section{H. Pengumpulan dan Pengolahan Data}

Terdapat dua teknik pengumpulan data. Pertama, tabel transaksi I-O desa diturunkan dari tabel transaksi I-O kabupaten dengan menggunakan metode RAS. Kedua, tabel transaksi I-O pedesaan dibangun sendiri dengan memasukkan kegiatan GERHAN, khususnya PKT sebagai salah satu sektor perekonomian pedesaan. Penelitian ini menggunakan teknik yang kedua. Data untuk menyusun tabel transaksi I-O desa diperoleh 
melalui survey lapangan dan estimasi. Hasil penyusunan klasifikasi sektor tabel input output tiga desa contoh disajikan pada Lampiran 2 hingga Lampiran 4. Pengolahan data I-O dilakukan dengan menggunakan GRIMP-7 (West, 1993). Hasil pengolahan data disajikan pada Lampiran 5 hingga Lampiran 16.

\section{HASIL DAN PEMBAHASAN}

\section{A. Dampak Pengganda Output}

Dampak pengganda output adalah dampak adanya kenaikan permintaan akhir terhadap output dari suatu sektor terhadap total output seluruh sektor dalam perekonomian suatu wilayah tertentu. Permintaan akhir adalah permintaan yang tidak digunakan dalam proses produksi. Termasuk ke dalam permintaan akhir yaitu: konsumsi rumah tangga, pembentukkan kapital, konsumsi pemerintah, dan ekspor. Permintaan yang digunakan dalam proses produksi biasa disebut permintaan antara. Sesuai tujuan, output suatu sektor yang menjadi pusat perhatian adalah output kegiatan PKT yang diwakili oleh kegiatan pembibitan. Sedangkan wilayah perekonomian yang dikaji adalah wilayah desa.

Hasil penelitian menunjukkan bahwa dampak pengganda output dari kegiatan pembibitan di desa Gerhan contoh (Jabar: Desa Sirnaya, Jateng: Desa Golo dan Jatim: Desa Margomulyo) berkisar antara 1,000 1,017 untuk tipe I (tidak memperhitungkan induksi konsumsi) dan untuk tipe II (memperhitungkan induksi konsumsi) berkisar antara 1,182 1,541 (Tabel 2). Nilai dampak pengganda output dari sektor pembibitan di desa Gerhan contoh sebesar 1,541 memiliki arti bahwa jika permintaan akhir terhadap output dari sektor pembibitan meningkat sebesar satu satuan moneter, maka total output seluruh sektor dalam perekonomian desa Gerhan contoh akan meningkat sebesar 1,541 satuan moneter. Dengan kata lain, jika pemerintah mengeluarkan anggaran sebesar satu juta rupiah untuk pembelian bibit tanaman hutan, maka total ouput seluruh sektor dalam perekonomian desa Gerhan dapat diharapkan akan meningkat sebesar Rp 1,541 juta (satu juta lima ratus empat puluh satu ribu rupiah). Dengan demikian, dampak pengganda output dari kegiatan pembibitan adalah kecil; tidak ada standar baku berapa ukuran yang besar namun setidaknya jika dibandingkan dengan sektor lain untuk tipe II yang bisa mencapai lebih dari 2 (Sirnajaya: kentang; Golo: angkutan; Margomulyo: jagung) (periksa Lampiran 2, 3 dan 4 serta 5, 9 dan 13), dampak pengganda output dari sektor pembibitan tergolong kecil. 
Tabel 2. Dampak Pengganda Output Industri (Sektor) Pembibitan dalam Perekonomian Desa Gerhan, 2004

\begin{tabular}{|c|c|c|}
\hline \multirow{2}{*}{ Desa Contoh } & \multicolumn{2}{|c|}{ Dampak Pengganda Output } \\
\cline { 2 - 3 } & Type I & Type II \\
\hline $\begin{array}{c}\text { Jabar : Sirnajaya } \\
\text { Bibit tanaman hutan }\end{array}$ & 1,017 & 1,271 \\
$\begin{array}{c}\text { Jateng : Golo* } \\
\text { Bibit tanaman hutan } \\
\begin{array}{c}\text { Jatim : Margomulyo* } \\
\text { Bibit tanaman hutan }\end{array}\end{array}$ & 1,000 & 1,182 \\
\hline
\end{tabular}

* realisasi Gerhan terluas

\section{B. Dampak Pengganda Pendapatan}

Dampak pengganda pendapatan adalah dampak adanya kenaikan permintaan akhir terhadap output dari suatu sektor terhadap total income seluruh sektor dalam perekonomian suatu wilayah tertentu. Hasil penelitian menunjukkan bahwa dampak pengganda pendapatan dari kegiatan pembibitan di desa Gerhan contoh (Jabar: Desa Sirnaya, Jateng: Desa Golo dan Jatim: Desa Margomulyo) berkisar antara 1,000 - 1,022 untuk tipe I (tidak mempertimbangkan induksi konsumsi) dan untuk tipe II (mempertimbangkan induksi konsumsi) berkisar antara 1,182 - 1,694 (Tabel 3). Nilai dampak pengganda pendapatan dari sektor pembibitan di desa Gerhan contoh sebesar 1,694 memiliki arti bahwa jika permintaan akhir terhadap output dari sektor pembibitan meningkat sebesar satu satuan moneter, maka total pendapatan rumah tangga seluruh sektor dalam perekonomian desa Gerhan contoh akan meningkat sebesar 1,694 satuan moneter. Dengan kata lain, jika pemerintah mengeluarkan anggaran sebesar satu juta rupiah untuk pembelian bibit tanaman hutan, maka total pendapatan rumah tangga seluruh sektor dalam perekonomian desa Gerhan dapat diharapkan akan meningkat sebesar Rp 1,694 juta (satu juta enam ratus sembilan puluh empat ribu rupiah). Dengan demikian, dampak pengganda pendapatan dari kegiatan pembibitan adalah kecil; tidak ada standar baku berapa ukuran yang besar namun setidaknya jika dibandingkan dengan sektor lain untuk tipe II yang bisa mencapai lebih dari 2 (Sirnajaya: tembakau rajang; Golo: angkutan; Margomulyo: industri tahu) (periksa Lampiran 2, 3 dan 4 serta 6,10 dan 14); dampak pengganda pendapatan dari sektor pembibitan tergolong kecil. 
Tabel 3. Dampak Pengganda Pendapatan Sektor Pembibitan dalam Perekonomian Desa Gerhan, 2004

\begin{tabular}{|c|c|c|}
\hline \multirow{2}{*}{ Desa Contoh } & \multicolumn{2}{|c|}{ Dampak Pengganda Pendapatan } \\
\cline { 2 - 3 } & Type I & Type II \\
\hline $\begin{array}{c}\text { Jabar : Sirnajaya } \\
\text { Bibit tanaman hutan } \\
\text { Jateng : Golo* } \\
\text { Bibit tanaman hutan } \\
\begin{array}{c}\text { Jatim : Margomulyo* } \\
\text { Bibit tanaman hutan }\end{array}\end{array}$ & 1,022 & 1,694 \\
& 1,000 & 1,182 \\
\end{tabular}

* realisasi Gerhan terluas

\section{Dampak Pengganda Tenaga Kerja}

Dampak pengganda tenaga kerja adalah dampak adanya kenaikan permintaan akhir terhadap output dari suatu sektor terhadap total employment seluruh sektor dalam perekonomian suatu wilayah tertentu. Hasil penelitian menunjukkan bahwa dampak pengganda tenaga kerja dari kegiatan pembibitan di desa Gerhan contoh (Jabar: Desa Sirnaya, Jateng: Desa Golo dan Jatim: Desa Margomulyo) berkisar antara 1,000 1,002 untuk tipe I (tidak mempertimbangkan induksi konsumsi) dan untuk tipe II (mempertimbangkan induksi konsumsi) berkisar antara 1,001 1,032 (Tabel 4). Nilai dampak pengganda tenaga kerja dari sektor pembibitan di desa Gerhan contoh sebesar 1,032 memiliki arti bahwa jika permintaan akhir terhadap output dari sektor pembibitan meningkat sebesar satu satuan moneter, maka total serapan tenaga kerja seluruh sektor dalam perekonomian desa Gerhan contoh akan meningkat sebesar 1,032 tenaga kerja (menciptakan satu orang tenaga kerja). Dengan kata lain, jika pemerintah mengeluarkan anggaran sebesar satu juta rupiah untuk pembelian bibit tanaman hutan, maka total tenaga kerja seluruh sektor dalam perekonomian desa Gerhan dapat diharapkan akan meningkat sebesar 1,032 tenaga kerja. Dengan demikian, dampak pengganda tenaga kerja dari kegiatan pembibitan adalah kecil; tidak ada standar baku berapa ukuran yang besar namun setidaknya jika dibandingkan dengan sektor lain untuk tipe II yang bisa mencapai lebih dari 2 (Sirnajaya: perdagangan; Golo: angkutan; Margomulyo: industri tahu) (periksa Lampiran 2, 3 dan 4 serta 7, 11 dan 15); dampak pengganda tenaga kerja dari sektor pembibitan tergolong kecil. 
Tabel 4. Dampak Pengganda Tenaga Kerja Sektor Pembibitan dalam Perekonomian Desa Gerhan, 2004

\begin{tabular}{|l|c|c|}
\hline \multirow{2}{*}{ Desa Contoh } & \multicolumn{2}{|c|}{ Dampak Pengganda Tenaga Kerja } \\
\cline { 2 - 3 } & Type I & Type II \\
\hline $\begin{array}{c}\text { Jabar : Sirnajaya } \\
\text { Bibit tanaman hutan }\end{array}$ & 1,002 & 1,032 \\
Jateng : Golo* \\
$\begin{array}{c}\text { Bibit tanaman hutan } \\
\text { Jatim : Margomulyo* } \\
\text { Bibit tanaman hutan }\end{array}$ & 1,000 & 1,001 \\
& 1,000 & 1,010 \\
\hline
\end{tabular}

* realisasi Gerhan terluas

\section{Keterkaitan Langsung dengan Sektor Lain}

Keterkaitan langsung ke depan menunjukkan pengaruh perubahan output suatu sektor tertentu (akibat perubahan permintaan akhir) terhadap sektor-sektor yang menggunakan sebagian output sektor yang bersangkutan secara langsung. Keterkaitan ke depan muncul karena adanya supply imput dengan asumsi supply menciptakan demandnya sendiri. Asumsi demikian penting dikedepankan karena output suatu industri tidak begitu saja dapat menciptakan industri lanjutan karena masih memerlukan imput-input lain. Adanya output suatu industri baru merupakan syarat perlu (necessary condition) dan belum merupakan syarat cukup (sufficient condition) bagi munculnya industri lanjutan yang memanfaatkan output tersebut. Keterkaitan langsung ke depan akan semakin rendah bila output sektor yang bersangkutan didistribusikan langsung ke konsumen atau diekspor ke luar daerah (permintaan akhir) tanpa pengolahan terlebih dahulu. Pada Tabel 5 terlihat bahwa keterkaitan langsung ke depan sektor pembibitan adalah rendah. Hal demikian dapat dipahami karena bibit tanaman hutan tidak banyak digunakan langsung oleh sektor-sektor lain kecuali oleh sektor tegakan hutan. Lebih jauh, bibit tanaman hutan di desa Gerhan sebagian besar dijual ke luar desa (diekspor) karena permintaan bibit oleh kontraktor Gerhan yang berada di luar desa Gerhan.

Sedangkan keterkaitan langsung ke belakang menunjukkan pengaruh perubahan output suatu sektor tertentu (akibat perubahan permintaan akhir) terhadap sektor-sektor yang menyediakan input antara bagi sektor yang bersangkutan secara langsung. Kaitan ke belakang muncul karena adanya permintaan input. Bila sumber-sumber dan teknologi yang dipergunakan diperoleh dari produksi setempat atau lokal, maka pengaruhnya akan maksimal, dan sebaliknya, bila dari impor, maka pengaruhnya akan minimal karena bocor ke luar daerah. Pada Tabel 5 terlihat bahwa keterkaitan langsung ke belakang sektor pembibitan adalah rendah. Hal demikian dapat dimaklumi karena bibit tanaman hutan hampir tidak menggunakan input produksi lokal. Kantung plastik misalnya dibeli dari luar desa dan bahkan sebagian besar saprodi seperti pupuk dan obat-obatan juga dibeli dari luar desa. Lebih jauh, benih tanaman hutan sebagian juga diperoleh dari luar desa, karena budidaya benih belum berkembang. 
Tabel5. Keterkaitan Langsung ke Depan dan ke Belakang Sektor Pembibitan dalam Perekonomian Desa Gerhan, 2004

\begin{tabular}{|l|c|c|}
\hline \multirow{2}{*}{ Desa Contoh } & \multicolumn{2}{|c|}{ Keterkaitan Langsung } \\
\cline { 2 - 3 } & Ke Depan & Ke Belakang \\
\hline $\begin{array}{c}\text { Jabar : Sirnajaya } \\
\text { Bibit tanaman hutan }\end{array}$ & 0,000 & 0,015 \\
$\begin{array}{c}\text { Jateng : Golo* } \\
\text { Bibit tanaman hutan } \\
\text { Jatim : Margomulyo* } \\
\text { Bibit tanaman hutan }\end{array}$ & 0,000 & 0,000 \\
\hline
\end{tabular}

* realisasi Gerhan terluas

\section{E. Keterkaitan Langsung dan Tidak Langsung dengan Sektor Lain}

Keterkaitan langsung dan tidak langsung ke depan menunjukkan pengaruh perubahan output suatu sektor tertentu (akibat perubahan dari permintaan akhir) terhadap sektor-sektor yang menggunakan output sektor yang bersangkutan baik secara langsung maupun tidak langsung. Sedangkan keterkaitan langsung dan tidak langsung ke belakang menunjukkan pengaruh perubahan output suatu sektor tertentu akibat perubahan per unit outputpermintaan akhir terhadap sektor-sektor yang menyediakan input antara bagi sektor yang bersangkutan baik secara langsung maupun tidak langsung. Pada Tabel 6 terlihat bahwa keterkaitan langsung dan tidak langsung ke depan dan ke belakang sektor bibit tanaman hutan adalah rendah. Hal demikian dapat dipahami karena, sebagaimana telah dijelaskan, sektor bibit tanaman hutan di samping tidak banyak menggunakan input produksi lokal (keterkaitan ke belakang), juga sebagian besar outputnya dijual ke luar desa (keterkaitan ke depan).

Tabel 6. Keterkaitan Langsung dan Tidak Langsung ke Depan dan ke Belakang Sektor Pembibitan dalam Perekonomian Desa Gerhan, 2004

\begin{tabular}{|c|c|c|}
\hline \multirow{2}{*}{ Desa Contoh } & \multicolumn{2}{|c|}{ Keterkaitan Langsung dan Tidak Langsung } \\
\cline { 2 - 3 } & Ke Depan & Ke Belakang \\
\hline $\begin{array}{c}\text { Jabar : Sirnajaya } \\
\text { Bibit tanaman hutan } \\
\begin{array}{c}\text { Jateng : Golo* } \\
\text { Bibit tanaman hutan } \\
\text { Jatim : Margomulyo* } \\
\text { Bibit tanaman hutan }\end{array}\end{array}$ & 1.000 & 1.021 \\
\hline
\end{tabular}

* realisasi Gerhan terluas 


\section{F. Dampak Penyebaran}

Keterkaitan langsung dan tidak langsung baik ke depan maupun ke belakang belum memadai dipakai sebagai landasan pemilihan sektor kunci. Sebab, mungkin saja suatu sektor yang pengaruh keterkaitannya lemah namun mempunyai pangsa yang besar terhadap produksi total. Ukuran yang membobotkan kedua pertimbangan tersebut dikenal sebagai dampak penyebaran suatu sektor. Dampak penyebaran dibedakan ke dalam dua macam, yaitu: (1) daya tarik atau daya penyebaran (power of dispersion), yang diperoleh dari hasil pembobotan nilai keterkaitan ke belakang, dan (2) daya dorong atau kepekaan penyebaran (sensitivity of dispersion), yang diperoleh dari hasil pembobotan keterkaitan ke depan.

Konsep daya tarik berguna untuk mengetahui distribusi manfaat dari pengembangan suatu sektor terhadap perkembangan sektor-sektor lain melalui mekanisme transaksi pasar input. Konsep daya tarik juga sering diartikan sebagai kemampuan suatu sektor untuk meningkatkan pertumbuhan industri hulu. Suatu sektor dikatakan mempunyai rangsangan yang tinggi terhadap sektor lain bila memiliki nilai daya tariknya lebih besar dari satu, dan sebaliknya, mempunyai rangsangan rendah bila nilai daya tariknya lebih kecil dari satu. Pada Tabel 7 terlihat bahwa daya tarik dari sektor pembibitan adalah kurang dari satu. Ini menunjukkan bahwa kegiatan pembibitan lebih banyak menggunakan input impor dibanding inputproduksi lokal.

Sedangkan konsep daya dorong bermanfaat untuk mengetahui tingkat kepekaan suatu sektor terhadap sektor-sektor lain melalui mekanisme pasar output. Konsep daya dorong sering juga diartikan sebagai kemampuan suatu sektor tertentu untuk mendorong pertumbuhan produksi sektor-sektor lain yang memakai imput dari sektor yang bersangkutan. Suatu sektor dikatakan mempunyai rangsangan yang tinggi terhadap sektor lain bila nilai daya dorongnya lebih besar dari satu, dan sebaliknya, memiliki rangsangan yang rendah bila nilai daya dorongnya kurang dari satu. Pada Tabel 7 terlihat bahwa daya dorong dari sektor pembibitan adalah kurang dari satu. Ini menunjukkan bahwa kegiatan pembibitan lebih banyak diekspor daripada digunakan oleh sektor-sektor dalam perekonomian desa Gerhan.

Tabel 7. Dampak Penyebaran Sektor Pembibitan dalam Perekonomian Desa Gerhan, 2004

\begin{tabular}{|c|c|c|}
\hline \multirow{2}{*}{ Desa Contoh } & \multicolumn{2}{|c|}{ Dampak Penyebaran } \\
\hline & Daya Dorong & Daya Tarik \\
\hline Jabar: Sirnajaya & & \\
\hline Bibit tanaman hutan & 0,712 & 0,727 \\
\hline Jateng : Golo* & & \\
\hline Bibit tanaman hutan & 0,792 & 0,792 \\
\hline Jatim : Margomulyo* & & \\
\hline Bibit tanaman hutan & 0,877 & 0,877 \\
\hline
\end{tabular}

* realisasi Gerhan terluas 


\section{KESIMPULAN DAN SARAN}

\section{A. Kesimpulan}

Dampak pengganda industri (sektor) pembibitan Gerhan dalam perekonomian desa Gerhan adalah kecil. Hal ini disebabkan oleh tiga faktor. Pertama, output bibit tanaman hutan tidak banyak digunakan sebagai input oleh sektor lain. Kedua, output bibit tanaman hutan banyak menggunakan input dari luar desa (impor) dan hanya sedikit menggunakan input produksi lokal. Ketiga, output bibit yang berasal dari desa Gerhan lebih banyak dijual ke luar desa. Faktor penyebab pertama bersifat alamiah dan dua faktor penyebab terakhir merupakan dampak kebijakan Gerhan.

\section{B. Kesimpulan}

Dua faktor penyebab kecilnya dampak pengganda industri (sektor) pembibitan Gerhan dalam perekonomian desa Gerhan: (1) output bibit tanaman hutan banyak menggunakan input dari luar desa (impor) dan hanya sedikit menggunakan imputproduksi lokal, dan (2) output bibit yang berasal dari desa Gerhan lebih banyak dijual ke luar desa, menyarankan bahwa perbaikan atas dampak pengganda Gerhan dalam perekonomian desa Gerhan dapat dilakukan melalui perubahan kebijakan. Pertama, kebijakan Gerhan perlu lebih mengutamakan sumberdaya lokal misalnya pupuk kandang dan pengembangan pembenihan di lokasi desa Gerhan. Kebijakan demikian dapat mendorong tumbuhnya kegiatan ekonomi lain yang terkait Gerhan dengan lebih tajam. Kedua, kebijakan Gerhan yang mengabaikan lokasi kontraktor bibit perlu diubah ke arah lebih mengutamakan tumbuhnya kontraktor bibit tanaman di lokasi desa Gerhan. Sejauh mungkin perlu dihindari munculnya kontraktor bibit tanaman Gerhan yang berada di luar desa Gerhan. Sebagai desa dengan lahan kritis, desa Gerhan sewajarnya memperoleh perlakuan kebijakan-kebijakan demikian. Terlebih jika di desa-desa Gerhan, sektor perbenihan dan pembibitan serta sektor tegakan hutan dan industri pengolahan kayu diharapkan berkembang menjadi sektor ekonomi dominan di samping sektor-sektor lain yang telah berkembang.

\section{DAFTAR PUSTAKA}

Cox, B. M. and Ian A. Munn. 2001. A Comparison of Two Input-Output Approaches for Investigating Regional Impacts of the Forest Products Industry in the Pacific Northwest and the South. Forest Product Journal 51 (6): 39-46.

Darusman, D. 1989. Analisis Dampak Ekonomi Industri Pengolahan Hasil Hutan di Pulau Jawa serta Strategi Pengembangannya: Suatu Studi Pembangunan Wilayah. Program Pasca Sarjana Institut Pertanian Bogor, Bogor.

Daryanto, A. 1990. Structural Interdependence, Structural Change of The Indonesian Economy With Emphasis on Agricultural Sector, 1971-1985; An Input-Output Analysis. Univ. of New England.

1995. Applications of Input-Output Analysis. Department of Socio-economic Sciences. Bogor Agricultural Univ. 
Menko Kesra/Ketua TKPLRRN. 2003. Lampiran Keputusan Menko Kesra /KetuaTKPLRRN No. 18 / KEP / MENKO / KESRA /X / 2003, Jakarta.

Richardson, Harry W. 1972. Input-Output and Regional Economics. Halstead Press, New York.

Ditjen RLPS. 2004. Rekapitulasi Hasil Monitoring Pengembangan Kelembagaan Gerakan Nasional Rehabilitasi Hutan dan Lahan (Gerhan) di 5 Propinsi di Jawa. Ditjen RLPS, Jakarta.

West, G. R. 1993. Input-Output Analysis for Practitioners. Version 7.1. User's Guide. Univ. of Queensland. 
Lampiran 1. Realisasi Program Gerhan Tahun 2004

\begin{tabular}{|c|c|c|c|c|}
\hline \multirow[b]{2}{*}{ Propinsi/Kabupaten } & \multirow[b]{2}{*}{ DAS } & \multicolumn{3}{|c|}{ Realisasi Fisik } \\
\hline & & $\begin{array}{l}\text { Reboisasi } \\
\text { (ha) }\end{array}$ & $\begin{array}{c}\text { Hutan Rakyat } \\
\text { (ha) }\end{array}$ & $\begin{array}{l}\text { Bangunan } \\
\text { Konservasi } \\
\text { Tanah (unit) }\end{array}$ \\
\hline \multicolumn{5}{|l|}{ Jawa Barat } \\
\hline Sumedang & $\begin{array}{l}\text { Cimanuk, } \\
\text { Citarum }\end{array}$ & 0 & 2205 & $38^{1)}$ \\
\hline Garut & Cimanuk & 0 & 1300 & 32) \\
\hline Majalengka & Cimanuk & 0 & 1895 & 0 \\
\hline \multicolumn{5}{|l|}{ Jawa Tengah } \\
\hline Wonogiri & Bengawan Solo & 0 & 5031 & $80^{3)}$ \\
\hline Boyolali & $\begin{array}{l}\text { Bengawan Solo, } \\
\text { Jratun Seluna }\end{array}$ & 0 & 2730 & $50^{4)}$ \\
\hline Semarang & Jratun Seluna & 0 & 2827 & 0 \\
\hline \multicolumn{5}{|l|}{ DI Yogyakarta } \\
\hline Sleman & Opak Oyo Progo & 0 & 1450 & 0 \\
\hline Bantul & Opak Oyo Progo & 0 & 2450 & 0 \\
\hline Kulon Progo & Opak Oyo Progo & 0 & 1650 & 0 \\
\hline Gunung Kidul & Opak Oyo Progo & 0 & 1195 & 0 \\
\hline \multicolumn{5}{|l|}{ Jawa Timur } \\
\hline Madiun & $\begin{array}{l}\text { Brantas, } \\
\text { Bengawan Solo }\end{array}$ & 0 & 1725 & 0 \\
\hline Blitar & Brantas & 0 & 1700 & 55) \\
\hline Bojonegoro & $\begin{array}{l}\text { Brantas, } \\
\text { Bengawan Solo }\end{array}$ & 0 & 8000 & 0 \\
\hline
\end{tabular}


Lampiran 2. Klasifikasi 37 x 37 Sektor Tabel Input Output Desa Gerhan Sirnajaya Tahun 2004

\begin{tabular}{|c|c|c|c|}
\hline No & Sektor & No & Sektor \\
\hline 1 & Bibit tanaman hutan & 32 & Jasa Dukun Terlatih \\
\hline 2 & Tegakan Hutan & 33 & Jasa Pijat \\
\hline 3 & Tanaman Padi & 34 & Tukang Bangunan \\
\hline 4 & Tanaman Bambu & 35 & Jasa Bajak \\
\hline 5 & Tanaman Jagung & 36 & Air Bersih \\
\hline 6 & Tanaman Kentang & 37 & Bangunan \\
\hline 7 & Tanaman Tomat & & \\
\hline 8 & Tanaman Kol & & \\
\hline 9 & Tanaman Kacang & 180 & Jumlah Permintaan Antara \\
\hline 10 & Tanaman teh & 190 & Jumlah Input Antara \\
\hline 11 & Tanaman Kopi & 200 & Impor \\
\hline 12 & Tanaman Jeruk & 201 & Upah dan Gaji \\
\hline 13 & Tanaman Tembakau & 202 & Surplus Usaha \\
\hline 14 & Peternak Susu (Sapi Perah) & 203 & Penyusutan \\
\hline 15 & Peternak Domba & 204 & Pajak tak Langsung \\
\hline 16 & Tembakau Rajang & 205 & Subsidi \\
\hline 17 & Kerajinan (Pandai) Alumunium & 209 & Nilai Tambah Bruto \\
\hline 18 & Kerajinan Bambu & 210 & Jumlah Input \\
\hline 19 & Penggilingan Padi & 301 & $\begin{array}{l}\text { Pengeluaran Konsumsi Rumah } \\
\text { Tangga }\end{array}$ \\
\hline 20 & Pedagang Gorengan & 302 & $\begin{array}{l}\text { Pengeluaran Konsumsi } \\
\text { Pemerintah }\end{array}$ \\
\hline 21 & Pedagang Lotek & 303 & Pembentukan Modal Tetap \\
\hline 22 & Pedagang Cilok & 304 & Perubahan Stok \\
\hline 23 & Pedagang Es Mambo & 305 & Ekspor Barang dan Jasa \\
\hline 24 & Pedagang Bandros & 309 & Jumlah Permintaan Akhir \\
\hline 25 & Pedagang Bakso & 310 & Jumlah Permintaan \\
\hline 26 & Pedagang Tembakau & 409 & Jumlah Impor Barang dan Jasa \\
\hline 27 & Warung Saprodi Pertanian & 509 & $\begin{array}{l}\text { Margin Perdagangan dan Biaya } \\
\text { Pengangkutan }\end{array}$ \\
\hline 28 & Warung Sembako & 600 & Jumlah Output \\
\hline 29 & Angkutan Ojek & 700 & Jumlah Penyediaan \\
\hline 30 & Angkutan Colt Bak & & \\
\hline 31 & Jasa Jahit & & \\
\hline
\end{tabular}


Lampiran 3. Klasifikasi 29x29 Sektor Tabel Input Output Desa Gerhan Golo Tahun 2004

\begin{tabular}{|c|l|c|l|}
\hline No & \multicolumn{1}{|c|}{ Sektor } & No & \\
\hline 1 & Padi ladang & 27 & Tukang batu \\
2 & Jagung & 28 & Tukang pijat \\
3 & Ubi kayu & 29 & Bangunan \\
4 & Cengkeh & & \\
5 & Jahe & 180 & \\
6 & Kunyit & 190 & Jumlah Permintaan Antara \\
7 & Bibit Tanaman Hutan & 200 & Impor Input Antara \\
8 & Tegakan Hutan & 201 & Upah dan Gaji \\
9 & Sapi & 202 & Surplus Usaha \\
10 & Kambing & 203 & Penyusutan \\
11 & Kerajinan tikar & 204 & Pajak tak Langsung \\
12 & Jasa Penebangan Kayu & 205 & Subsidi \\
13 & Industri Mebel Kayu & 209 & Nilai Tambah Bruto \\
14 & Kerupuk & 210 & Jumlah Input \\
15 & Warung kelontong & 301 & Pengeluaran Konsumsi Rumah Tangga \\
16 & Tengkulak palawija & 302 & Pengeluaran Konsumsi Pemerintah \\
17 & Tengkulak sapi & 303 & Pembentukan Modal Tetap \\
18 & Tengkulak kambing & 304 & Perubahan Stok \\
19 & Warung makan & 305 & Ekspor Barang dan Jasa \\
20 & Truk & 309 & Jumlah Permintaan Akhir \\
21 & Angkutan Pedesaan & 310 & Jumlah Permintaan \\
22 & Ojek & 409 & Jumlah Impor Barang dan Jasa \\
23 & Dukun bayi & 509 & Margin Perdagangan dan Biaya \\
24 & Simpan pinjam & & Pengangkutan \\
25 & Karawitan & 600 & Jumlah Output \\
26 & Tukang kayu & 700 & Jumlah Penyediaan \\
\hline & & \\
\hline
\end{tabular}


Lampiran 4. Klasifikasi 22x22 Sektor Tabel Input Output Desa Gerhan Margomulyo Tahun 2004

\begin{tabular}{|c|l|c|l|}
\hline No & \multicolumn{1}{|c|}{ Sektor } & No & \multicolumn{1}{|c|}{ Sektor } \\
\hline 1 & Padi & 180 & Jumlah Permintaan Antara \\
2 & Jagung & 190 & Jumlah Input Antara \\
3 & Kedele & 200 & Impor \\
4 & Tebu & 201 & Upah dan Gaji \\
5 & Lombok & 202 & Surplus Usaha \\
6 & Kambing & 203 & Penyusutan \\
7 & Sapi & 204 & Pajak tak Langsung \\
8 & Bibit Tanaman Hutan & 205 & Subsidi \\
9 & Tahu & 209 & Nilai Tambah Bruto \\
10 & Tegakan Hutan & 210 & Jumlah Input \\
11 & Meubel & 301 & Pengeluaran Konsumsi Rumah Tangga \\
12 & Tukang Batu & 302 & Pengeluaran Konsumsi Pemerintah \\
13 & Tukang besi & 303 & Pembentukan Modal Tetap \\
14 & Pedagang sapi & 304 & Perubahan Stok \\
15 & Pedagang kambing & 305 & Ekspor Barang dan Jasa \\
16 & Warung makan & 309 & Jumlah Permintaan Akhir \\
17 & Angkutan & 310 & Jumlah Permintaan \\
18 & Bengkel & 409 & Jumlah Impor Barang dan Jasa \\
19 & Spareparts & 509 & Margin Perdagangan dan Biaya \\
20 & Wartel & & Pengangkutan \\
\cline { 2 - 3 } 21 & Dalang & 600 & Jumlah Output \\
22 & Bangunan & 700 & Jumlah Penyediaan \\
\hline
\end{tabular}


Lampiran 5. Dampak Pengganda Output dalam Perekonomian Desa Gerhan Sirnajaya Tahun 2004

\begin{tabular}{|c|c|c|c|c|c|c|c|c|}
\hline SECTOR & INITIAL & FIRST & INDUST & TOTAL & CONS'M & TOTAL & TYPE I & TYPE II \\
\hline 1 & 1.000 & 0.015 & 0.002 & 1.017 & 0.254 & 1.271 & 1.017 & 1.271 \\
\hline 2 & 1.000 & 0.037 & 0.008 & 1.045 & 0.232 & 1.277 & 1.045 & 1.277 \\
\hline 3 & 1.000 & 0.276 & 0.081 & 1.356 & 0.251 & 1.607 & 1.356 & 1.607 \\
\hline 4 & 1.000 & 0.000 & 0.000 & 1.000 & 0.000 & 1.000 & 1.000 & 1.000 \\
\hline 5 & 1.000 & 0.200 & 0.044 & 1.244 & 0.109 & 1.353 & 1.244 & 1.353 \\
\hline 6 & 1.000 & 0.699 & 0.637 & 2.335 & 0.460 & 2.795 & 2.335 & 2.795 \\
\hline 7 & 1.000 & 0.560 & 0.192 & 1.752 & 0.492 & 2.244 & 1.752 & 2.244 \\
\hline 8 & 1.000 & 0.338 & 0.099 & 1.437 & 0.522 & 1.959 & 1.437 & 1.959 \\
\hline 9 & 1.000 & 0.167 & 0.035 & 1.202 & 0.115 & 1.317 & 1.202 & 1.317 \\
\hline 10 & 1.000 & 0.201 & 0.038 & 1.239 & 0.204 & 1.443 & 1.239 & 1.443 \\
\hline 11 & 1.000 & 0.250 & 0.014 & 1.264 & 0.030 & 1.294 & 1.264 & 1.294 \\
\hline 12 & 1.000 & 0.020 & 0.001 & 1.021 & 0.531 & 1.552 & 1.021 & 1.552 \\
\hline 13 & 1.000 & 0.196 & 0.055 & 1.251 & 0.334 & 1.585 & 1.251 & 1.585 \\
\hline 14 & 1.000 & 0.224 & 0.031 & 1.255 & 0.224 & 1.479 & 1.255 & 1.479 \\
\hline 15 & 1.000 & 0.265 & 0.008 & 1.273 & 1.015 & 2.287 & 1.273 & 2.287 \\
\hline 16 & 1.000 & 0.734 & 0.180 & 1.914 & 0.462 & 2.377 & 1.914 & 2.377 \\
\hline 17 & 1.000 & 0.145 & 0.042 & 1.187 & 0.800 & 1.987 & 1.187 & 1.987 \\
\hline 18 & 1.000 & 0.368 & 0.008 & 1.376 & 0.235 & 1.611 & 1.376 & 1.611 \\
\hline 19 & 1.000 & 0.112 & 0.037 & 1.149 & 0.102 & 1.251 & 1.149 & 1.251 \\
\hline 20 & 1.000 & 0.512 & 0.097 & 1.609 & 0.435 & 2.044 & 1.609 & 2.044 \\
\hline 21 & 1.000 & 0.246 & 0.051 & 1.297 & 1.020 & 2.316 & 1.297 & 2.316 \\
\hline 22 & 1.000 & 0.451 & 0.079 & 1.530 & 0.647 & 2.178 & 1.530 & 2.178 \\
\hline 23 & 1.000 & 0.775 & 0.128 & 1.903 & 0.596 & 2.498 & 1.903 & 2.498 \\
\hline 24 & 1.000 & 0.533 & 0.110 & 1.643 & 0.801 & 2.444 & 1.643 & 2.444 \\
\hline 25 & 1.000 & 0.529 & 0.109 & 1.638 & 0.704 & 2.342 & 1.638 & 2.342 \\
\hline 26 & 1.000 & 0.733 & 0.318 & 2.052 & 0.410 & 2.461 & 2.052 & 2.461 \\
\hline 27 & 1.000 & 0.275 & 0.015 & 1.290 & 0.972 & 2.262 & 1.290 & 2.262 \\
\hline 28 & 1.000 & 0.187 & 0.007 & 1.194 & 0.951 & 2.145 & 1.194 & 2.145 \\
\hline 29 & 1.000 & 0.090 & 0.019 & 1.108 & 0.170 & 1.279 & 1.108 & 1.279 \\
\hline 30 & 1.000 & 0.048 & 0.010 & 1.058 & 0.119 & 1.177 & 1.058 & 1.177 \\
\hline 31 & 1.000 & 0.382 & 0.076 & 1.458 & 0.620 & 2.078 & 1.458 & 2.078 \\
\hline 32 & 1.000 & 0.077 & 0.026 & 1.103 & 0.248 & 1.351 & 1.103 & 1.351 \\
\hline 33 & 1.000 & 0.248 & 0.052 & 1.300 & 0.652 & 1.952 & 1.300 & 1.952 \\
\hline 34 & 1.000 & 0.044 & 0.021 & 1.065 & 0.035 & 1.100 & 1.065 & 1.100 \\
\hline 35 & 1.000 & 0.108 & 0.054 & 1.162 & 0.084 & 1.246 & 1.162 & 1.246 \\
\hline 36 & 1.000 & 0.000 & 0.000 & 1.000 & 0.232 & 1.232 & 1.000 & 1.232 \\
\hline 37 & 1.000 & 0.000 & 0.000 & 1.000 & 0.674 & 1.674 & 1.000 & 1.674 \\
\hline
\end{tabular}


Lampiran 6. Dampak Pengganda Pendapatan dalam Perekonomian Desa Gerhan Sirnajaya Tahun 2004

\begin{tabular}{|c|c|c|c|c|c|c|c|c|}
\hline SECTOR & INITLAL & FIRST & INDUST & TOTAL & $C O N S^{\prime} M$ & TOTAL & TYPE I & TYPE II \\
\hline 1 & 0.148 & 0.003 & 0.001 & 0.151 & 0.099 & 0.250 & 1.022 & 1.694 \\
\hline 2 & 0.125 & 0.011 & 0.002 & 0.138 & 0.091 & 0.228 & 1.105 & 1.831 \\
\hline 3 & 0.000 & 0.127 & 0.021 & 0.149 & 0.098 & 0.247 & 0.000 & 0.000 \\
\hline 4 & 0.000 & 0.000 & 0.000 & 0.000 & 0.000 & 0.000 & 0.000 & 0.000 \\
\hline 5 & 0.000 & 0.053 & 0.012 & 0.064 & 0.042 & 0.107 & 0.000 & 0.000 \\
\hline 6 & 0.000 & 0.139 & 0.134 & 0.273 & 0.180 & 0.453 & 0.000 & 0.000 \\
\hline 7 & 0.000 & 0.236 & 0.056 & 0.292 & 0.192 & 0.484 & 0.000 & 0.000 \\
\hline 8 & 0.120 & 0.163 & 0.026 & 0.310 & 0.204 & 0.513 & 2.572 & 4.264 \\
\hline 9 & 0.000 & 0.059 & 0.010 & 0.068 & 0.045 & 0.113 & 0.000 & 0.000 \\
\hline 10 & 0.049 & 0.061 & 0.011 & 0.121 & 0.079 & 0.200 & 2.446 & 4.055 \\
\hline 11 & 0.000 & 0.011 & 0.007 & 0.018 & 0.012 & 0.029 & 0.000 & 0.000 \\
\hline 12 & 0.314 & 0.001 & 0.001 & 0.315 & 0.207 & 0.522 & 1.004 & 1.665 \\
\hline 13 & 0.103 & 0.079 & 0.015 & 0.198 & 0.130 & 0.329 & 1.916 & 3.177 \\
\hline 14 & 0.095 & 0.030 & 0.008 & 0.133 & 0.088 & 0.221 & 1.404 & 2.328 \\
\hline 15 & 0.496 & 0.103 & 0.003 & 0.602 & 0.396 & 0.999 & 1.214 & 2.012 \\
\hline 16 & 0.094 & 0.115 & 0.066 & 0.274 & 0.180 & 0.455 & 2.927 & 4.852 \\
\hline 17 & 0.403 & 0.059 & 0.013 & 0.475 & 0.312 & 0.787 & 1.179 & 1.955 \\
\hline 18 & 0.089 & 0.047 & 0.003 & 0.139 & 0.092 & 0.231 & 1.560 & 2.587 \\
\hline 19 & 0.025 & 0.022 & 0.013 & 0.061 & 0.040 & 0.101 & 2.389 & 3.961 \\
\hline 20 & 0.000 & 0.227 & 0.031 & 0.258 & 0.170 & 0.428 & 0.000 & 0.000 \\
\hline 21 & 0.537 & 0.048 & 0.020 & 0.605 & 0.398 & 1.003 & 1.126 & 1.867 \\
\hline 22 & 0.191 & 0.166 & 0.028 & 0.384 & 0.253 & 0.637 & 2.017 & 3.343 \\
\hline 23 & 0.000 & 0.311 & 0.042 & 0.354 & 0.233 & 0.586 & 0.000 & 0.000 \\
\hline 24 & 0.209 & 0.228 & 0.038 & 0.475 & 0.313 & 0.788 & 2.279 & 3.778 \\
\hline 25 & 0.161 & 0.220 & 0.037 & 0.418 & 0.275 & 0.693 & 2.597 & 4.305 \\
\hline 26 & 0.000 & 0.174 & 0.069 & 0.243 & 0.160 & 0.403 & 0.000 & 0.000 \\
\hline 27 & 0.505 & 0.066 & 0.007 & 0.577 & 0.380 & 0.957 & 1.144 & 1.896 \\
\hline 28 & 0.501 & 0.061 & 0.003 & 0.564 & 0.371 & 0.936 & 1.127 & 1.869 \\
\hline 29 & 0.051 & 0.044 & 0.006 & 0.101 & 0.066 & 0.168 & 1.980 & 3.283 \\
\hline 30 & 0.044 & 0.023 & 0.003 & 0.071 & 0.047 & 0.117 & 1.608 & 2.666 \\
\hline 31 & 0.164 & 0.179 & 0.026 & 0.368 & 0.242 & 0.610 & 2.246 & 3.723 \\
\hline 32 & 0.108 & 0.030 & 0.010 & 0.147 & 0.097 & 0.244 & 1.369 & 2.270 \\
\hline 33 & 0.250 & 0.119 & 0.018 & 0.387 & 0.255 & 0.642 & 1.548 & 2.567 \\
\hline 34 & 0.000 & 0.012 & 0.008 & 0.021 & 0.014 & 0.034 & 0.000 & 0.000 \\
\hline 35 & 0.000 & 0.029 & 0.021 & 0.050 & 0.033 & 0.083 & 0.000 & 0.000 \\
\hline 36 & 0.138 & 0.000 & 0.000 & 0.138 & 0.091 & 0.229 & 1.000 & 1.658 \\
\hline 37 & 0.400 & 0.000 & 0.000 & 0.400 & 0.263 & 0.663 & 1.000 & 1.658 \\
\hline
\end{tabular}

Dampak Pengganda Industri Pembibitan .......... (Satria Astana, dkk.) 
Lampiran 7. Dampak Pengganda Tenaga Kerja dalam Perekonomian Desa Gerhan Sirnajaya Tahun 2004

\begin{tabular}{|c|c|c|c|c|c|c|c|c|}
\hline SECTOR & INITLAL & FIRST & INDUST & TOTAL & $C O N S^{\prime} M$ & TOTAL & TYPE I & TYPE II \\
\hline 1 & 0.000 & 0.000 & 0.000 & 0.000 & 0.000 & 0.000 & 1.002 & 1.032 \\
\hline 2 & 0.000 & 0.000 & 0.000 & 0.000 & 0.000 & 0.000 & 1.004 & 1.034 \\
\hline 3 & 0.000 & 0.000 & 0.000 & 0.000 & 0.000 & 0.000 & 1.027 & 1.033 \\
\hline 4 & 0.000 & 0.000 & 0.000 & 0.000 & 0.000 & 0.000 & 1.000 & 1.000 \\
\hline 5 & 0.000 & 0.000 & 0.000 & 0.000 & 0.000 & 0.000 & 1.054 & 1.055 \\
\hline 6 & 0.000 & 0.000 & 0.000 & 0.000 & 0.000 & 0.000 & 1.802 & 1.906 \\
\hline 7 & 0.000 & 0.000 & 0.000 & 0.000 & 0.000 & 0.000 & 1.130 & 1.189 \\
\hline 8 & 0.000 & 0.000 & 0.000 & 0.000 & 0.000 & 0.000 & 1.065 & 1.162 \\
\hline 9 & 0.000 & 0.000 & 0.000 & 0.000 & 0.000 & 0.000 & 1.001 & 1.002 \\
\hline 10 & 0.000 & 0.000 & 0.000 & 0.000 & 0.000 & 0.000 & 1.004 & 1.011 \\
\hline 11 & 0.000 & 0.000 & 0.000 & 0.000 & 0.000 & 0.000 & 1.000 & 1.001 \\
\hline 12 & 0.000 & 0.000 & 0.000 & 0.000 & 0.000 & 0.000 & 1.000 & 1.024 \\
\hline 13 & 0.000 & 0.000 & 0.000 & 0.000 & 0.000 & 0.000 & 1.054 & 1.061 \\
\hline 14 & 0.000 & 0.000 & 0.000 & 0.000 & 0.000 & 0.000 & 1.693 & 1.868 \\
\hline 15 & 0.000 & 0.000 & 0.000 & 0.000 & 0.000 & 0.000 & 1.033 & 1.252 \\
\hline 16 & 0.000 & 0.000 & 0.000 & 0.000 & 0.000 & 0.000 & 3.121 & 3.155 \\
\hline 17 & 0.000 & 0.000 & 0.000 & 0.000 & 0.000 & 0.000 & 1.253 & 1.890 \\
\hline 18 & 0.000 & 0.000 & 0.000 & 0.000 & 0.000 & 0.000 & 1.556 & 1.610 \\
\hline 19 & 0.000 & 0.000 & 0.000 & 0.000 & 0.000 & 0.000 & 1.037 & 1.057 \\
\hline 20 & 0.000 & 0.000 & 0.000 & 0.000 & 0.000 & 0.000 & 1.433 & 1.784 \\
\hline 21 & 0.000 & 0.000 & 0.000 & 0.000 & 0.000 & 0.000 & 1.491 & 2.214 \\
\hline 22 & 0.000 & 0.000 & 0.000 & 0.000 & 0.000 & 0.000 & 1.088 & 1.150 \\
\hline 23 & 0.000 & 0.000 & 0.000 & 0.000 & 0.000 & 0.000 & 2.806 & 3.779 \\
\hline 24 & 0.000 & 0.000 & 0.000 & 0.000 & 0.000 & 0.000 & 1.059 & 1.139 \\
\hline 25 & 0.000 & 0.000 & 0.000 & 0.000 & 0.000 & 0.000 & 1.650 & 2.374 \\
\hline 26 & 0.000 & 0.000 & 0.000 & 0.000 & 0.000 & 0.000 & 2.763 & 2.815 \\
\hline 27 & 0.000 & 0.000 & 0.000 & 0.000 & 0.000 & 0.000 & 1.229 & 2.671 \\
\hline 28 & 0.000 & 0.000 & 0.000 & 0.000 & 0.000 & 0.000 & 1.155 & 2.775 \\
\hline 29 & 0.000 & 0.000 & 0.000 & 0.000 & 0.000 & 0.000 & 1.104 & 1.336 \\
\hline 30 & 0.000 & 0.000 & 0.000 & 0.000 & 0.000 & 0.000 & 1.265 & 2.151 \\
\hline 31 & 0.000 & 0.000 & 0.000 & 0.000 & 0.000 & 0.000 & 1.072 & 1.203 \\
\hline 32 & 0.000 & 0.000 & 0.000 & 0.000 & 0.000 & 0.000 & 1.003 & 1.013 \\
\hline 33 & 0.000 & 0.000 & 0.000 & 0.000 & 0.000 & 0.000 & 1.009 & 1.034 \\
\hline 34 & 0.000 & 0.000 & 0.000 & 0.000 & 0.000 & 0.000 & 1.032 & 1.036 \\
\hline 35 & 0.000 & 0.000 & 0.000 & 0.000 & 0.000 & 0.000 & 1.162 & 1.180 \\
\hline 36 & 0.000 & 0.000 & 0.000 & 0.000 & 0.000 & 0.000 & 1.000 & 1.060 \\
\hline 37 & 0.000 & 0.000 & 0.000 & 0.000 & 0.000 & 0.000 & 1.000 & 2.868 \\
\hline
\end{tabular}


Lampiran 8. Keterkaitan Langsung serta Keterkaitan Langsung dan Tidak Langsung dan Dampak Penyebaran dalam Perekonomian Desa Gerhan Sirnajaya Tahun 2004

\begin{tabular}{|c|c|c|c|c|c|c|}
\hline \multirow{2}{*}{ Sektor } & \multicolumn{2}{|c|}{ Keterkaitan Langsung } & \multicolumn{2}{|c|}{$\begin{array}{l}\text { Keterkaitan Langsung dan } \\
\text { Tidak Langsung }\end{array}$} & \multicolumn{2}{|c|}{ Dampak Penyebaran } \\
\hline & Ke Depan & Ke Belakang & Ke Depan & Ke Belakang & $\begin{array}{c}\text { Derajat } \\
\text { Kepekaan }\end{array}$ & Daya Penyebaran \\
\hline 1 & 0.000 & 0.015 & 1.000 & 1.021 & 0.712 & 0.727 \\
\hline 2 & 0.000 & 0.037 & 1.000 & 1.062 & 0.712 & 0.755 \\
\hline 3 & 0.021 & 0.276 & 1.021 & 1.559 & 0.727 & 1.110 \\
\hline 4 & 0.247 & 0.000 & 1.289 & 1.000 & 0.918 & 0.712 \\
\hline 5 & 0.050 & 0.200 & 1.053 & 1.330 & 0.749 & 0.947 \\
\hline 6 & 0.417 & 0.699 & 1.714 & 2.707 & 1.220 & 1.927 \\
\hline 7 & 0.073 & 0.560 & 1.079 & 2.149 & 0.768 & 1.530 \\
\hline 8 & 0.041 & 0.338 & 1.043 & 1.693 & 0.743 & 1.205 \\
\hline 9 & 0.000 & 0.167 & 1.000 & 1.293 & 0.712 & 0.920 \\
\hline 10 & 0.000 & 0.201 & 1.000 & 1.333 & 0.712 & 0.949 \\
\hline 11 & 0.000 & 0.250 & 1.000 & 1.279 & 0.712 & 0.910 \\
\hline 12 & 0.000 & 0.020 & 1.000 & 1.022 & 0.712 & 0.727 \\
\hline 13 & 0.662 & 0.196 & 2.402 & 1.373 & 1.710 & 0.977 \\
\hline 14 & 0.105 & 0.224 & 1.133 & 1.290 & 0.806 & 0.918 \\
\hline 15 & 0.000 & 0.265 & 1.000 & 1.270 & 0.712 & 0.903 \\
\hline 16 & 0.316 & 0.734 & 2.096 & 2.028 & 1.492 & 1.443 \\
\hline 17 & 0.000 & 0.000 & 1.000 & 1.000 & 0.712 & 0.712 \\
\hline 18 & 0.000 & 0.145 & 1.000 & 1.250 & 0.712 & 0.889 \\
\hline 19 & 0.154 & 0.368 & 1.174 & 1.372 & 0.836 & 0.977 \\
\hline 20 & 0.136 & 0.112 & 1.224 & 1.136 & 0.871 & 0.809 \\
\hline 21 & 0.074 & 0.512 & 1.110 & 1.659 & 0.790 & 1.181 \\
\hline 22 & 0.040 & 0.246 & 1.053 & 1.299 & 0.750 & 0.924 \\
\hline 23 & 0.064 & 0.451 & 1.071 & 1.582 & 0.762 & 1.126 \\
\hline 24 & 0.097 & 0.775 & 1.128 & 1.986 & 0.803 & 1.413 \\
\hline 25 & 0.104 & 0.533 & 1.149 & 1.691 & 0.818 & 1.204 \\
\hline 26 & 0.000 & 0.529 & 1.000 & 1.681 & 0.712 & 1.196 \\
\hline 27 & 1.947 & 0.733 & 3.468 & 2.077 & 2.468 & 1.478 \\
\hline 28 & 2.861 & 0.275 & 4.122 & 1.300 & 2.933 & 0.925 \\
\hline 29 & 0.189 & 0.187 & 1.563 & 1.196 & 1.112 & 0.851 \\
\hline 30 & 0.536 & 0.090 & 1.621 & 1.118 & 1.154 & 0.795 \\
\hline 31 & 0.096 & 0.048 & 1.122 & 1.063 & 0.799 & 0.756 \\
\hline 32 & 0.000 & 0.382 & 1.000 & 1.501 & 0.712 & 1.068 \\
\hline 33 & 0.000 & 0.077 & 1.000 & 1.110 & 0.712 & 0.790 \\
\hline 34 & 0.000 & 0.248 & 1.000 & 1.319 & 0.712 & 0.939 \\
\hline 35 & 0.000 & 0.044 & 1.000 & 1.069 & 0.712 & 0.761 \\
\hline 36 & 0.515 & 0.108 & 1.561 & 1.174 & 1.111 & 0.836 \\
\hline 37 & 1.298 & 0.000 & 3.794 & 1.000 & 2.700 & 0.712 \\
\hline
\end{tabular}


Lampiran 9. Dampak Pengganda Output dalam Perekonomian Desa Gerhan Golo Tahun 2004

\begin{tabular}{|c|c|c|c|c|c|c|c|c|}
\hline SECTOR & INITIAL & FIRST & INDUST & TOTAL & $C O N S^{\prime} M$ & TOTAL & TYPE I & TYPE II \\
\hline 1 & 1.000 & 0.489 & 0.234 & 1.722 & 0.908 & 2.630 & 1.722 & 2.630 \\
\hline 2 & 1.000 & 0.141 & 0.044 & 1.184 & 1.285 & 2.470 & 1.184 & 2.470 \\
\hline 3 & 1.000 & 0.117 & 0.015 & 1.132 & 0.326 & 1.458 & 1.132 & 1.458 \\
\hline 4 & 1.000 & 0.000 & 0.000 & 1.000 & 0.107 & 1.107 & 1.000 & 1.107 \\
\hline 5 & 1.000 & 0.000 & 0.000 & 1.000 & 0.277 & 1.277 & 1.000 & 1.277 \\
\hline 6 & 1.000 & 0.000 & 0.000 & 1.000 & 0.403 & 1.403 & 1.000 & 1.403 \\
\hline 7 & 1.000 & 0.000 & 0.000 & 1.000 & 0.182 & 1.182 & 1.000 & 1.182 \\
\hline 8 & 1.000 & 0.000 & 0.000 & 1.000 & 0.204 & 1.204 & 1.000 & 1.204 \\
\hline 9 & 1.000 & 0.260 & 0.131 & 1.391 & 0.215 & 1.607 & 1.391 & 1.607 \\
\hline 10 & 1.000 & 0.420 & 0.133 & 1.553 & 0.890 & 2.443 & 1.553 & 2.443 \\
\hline 11 & 1.000 & 0.058 & 0.058 & 1.117 & 0.479 & 1.595 & 1.117 & 1.595 \\
\hline 12 & 1.000 & 0.178 & 0.023 & 1.201 & 0.895 & 2.097 & 1.201 & 2.097 \\
\hline 13 & 1.000 & 0.613 & 0.000 & 1.613 & 0.833 & 2.447 & 1.613 & 2.447 \\
\hline 14 & 1.000 & 0.141 & 0.140 & 1.281 & 0.455 & 1.736 & 1.281 & 1.736 \\
\hline 15 & 1.000 & 0.000 & 0.000 & 1.000 & 0.113 & 1.113 & 1.000 & 1.113 \\
\hline 16 & 1.000 & 0.487 & 0.176 & 1.663 & 0.617 & 2.279 & 1.663 & 2.279 \\
\hline 17 & 1.000 & 0.716 & 0.280 & 1.997 & 0.358 & 2.355 & 1.997 & 2.355 \\
\hline 18 & 1.000 & 0.069 & 0.038 & 1.107 & 0.135 & 1.242 & 1.107 & 1.242 \\
\hline 19 & 1.000 & 0.017 & 0.000 & 1.017 & 0.523 & 1.539 & 1.017 & 1.539 \\
\hline 20 & 1.000 & 0.620 & 0.617 & 2.237 & 0.268 & 2.505 & 2.237 & 2.505 \\
\hline 21 & 1.000 & 0.769 & 0.231 & 2.000 & 0.280 & 2.280 & 2.000 & 2.280 \\
\hline 22 & 1.000 & 0.083 & 0.017 & 1.100 & 0.075 & 1.175 & 1.100 & 1.175 \\
\hline 23 & 1.000 & 0.053 & 0.000 & 1.053 & 0.123 & 1.175 & 1.053 & 1.175 \\
\hline 24 & 1.000 & 0.089 & 0.064 & 1.153 & 0.233 & 1.386 & 1.153 & 1.386 \\
\hline 25 & 1.000 & 0.103 & 0.000 & 1.103 & 0.235 & 1.338 & 1.103 & 1.338 \\
\hline 26 & 1.000 & 0.000 & 0.000 & 1.000 & 1.120 & 2.120 & 1.000 & 2.120 \\
\hline 27 & 1.000 & 0.000 & 0.000 & 1.000 & 1.027 & 2.027 & 1.000 & 2.027 \\
\hline 28 & 1.000 & 0.286 & 0.000 & 1.286 & 0.736 & 2.022 & 1.286 & 2.022 \\
\hline 29 & 1.000 & 0.006 & 0.000 & 1.006 & 0.031 & 1.037 & 1.006 & 1.037 \\
\hline
\end{tabular}


Lampiran 10. Dampak Pengganda Pendapatan dalam Perekonomian Desa Gerhan Golo Tahun 2004

\begin{tabular}{|c|c|c|c|c|c|c|c|c|}
\hline SECTOR & INITLAL & FIRST & INDUST & TOTAL & $C O N S^{\prime} M$ & TOTAL & TYPE I & TYPE II \\
\hline 1 & 0.317 & 0.129 & 0.045 & 0.491 & 0.151 & 0.642 & 1.549 & 2.025 \\
\hline 2 & 0.620 & 0.064 & 0.011 & 0.695 & 0.213 & 0.908 & 1.122 & 1.465 \\
\hline 3 & 0.156 & 0.018 & 0.002 & 0.176 & 0.054 & 0.230 & 1.132 & 1.479 \\
\hline 4 & 0.058 & 0.000 & 0.000 & 0.058 & 0.018 & 0.076 & 1.000 & 1.307 \\
\hline 5 & 0.150 & 0.000 & 0.000 & 0.150 & 0.046 & 0.196 & 1.000 & 1.307 \\
\hline 6 & 0.218 & 0.000 & 0.000 & 0.218 & 0.067 & 0.285 & 1.000 & 1.307 \\
\hline 7 & 0.098 & 0.000 & 0.000 & 0.098 & 0.030 & 0.129 & 1.000 & 1.307 \\
\hline 8 & 0.110 & 0.000 & 0.000 & 0.110 & 0.034 & 0.144 & 1.000 & 1.307 \\
\hline 9 & 0.088 & 0.015 & 0.013 & 0.116 & 0.036 & 0.152 & 1.322 & 1.727 \\
\hline 10 & 0.364 & 0.089 & 0.029 & 0.481 & 0.148 & 0.629 & 1.324 & 1.729 \\
\hline 11 & 0.250 & 0.001 & 0.008 & 0.259 & 0.079 & 0.338 & 1.035 & 1.353 \\
\hline 12 & 0.425 & 0.053 & 0.007 & 0.484 & 0.149 & 0.633 & 1.140 & 1.490 \\
\hline 13 & 0.383 & 0.068 & 0.000 & 0.451 & 0.138 & 0.589 & 1.177 & 1.538 \\
\hline 14 & 0.225 & 0.001 & 0.020 & 0.246 & 0.076 & 0.322 & 1.094 & 1.430 \\
\hline 15 & 0.061 & 0.000 & 0.000 & 0.061 & 0.019 & 0.080 & 1.000 & 1.307 \\
\hline 16 & 0.028 & 0.253 & 0.053 & 0.334 & 0.102 & 0.436 & 11.814 & 15.437 \\
\hline 17 & 0.110 & 0.063 & 0.020 & 0.194 & 0.059 & 0.253 & 1.756 & 2.294 \\
\hline 18 & 0.040 & 0.025 & 0.008 & 0.073 & 0.022 & 0.095 & 1.833 & 2.395 \\
\hline 19 & 0.282 & 0.001 & 0.000 & 0.283 & 0.087 & 0.369 & 1.004 & 1.311 \\
\hline 20 & 0.025 & 0.068 & 0.052 & 0.145 & 0.044 & 0.189 & 5.869 & 7.669 \\
\hline 21 & 0.010 & 0.035 & 0.106 & 0.151 & 0.046 & 0.198 & 15.036 & 19.646 \\
\hline 22 & 0.000 & 0.035 & 0.005 & 0.040 & 0.012 & 0.053 & 0.000 & 0.000 \\
\hline 23 & 0.063 & 0.003 & 0.000 & 0.066 & 0.020 & 0.087 & 1.051 & 1.373 \\
\hline 24 & 0.082 & 0.028 & 0.015 & 0.126 & 0.039 & 0.164 & 1.531 & 2.000 \\
\hline 25 & 0.121 & 0.007 & 0.000 & 0.127 & 0.039 & 0.166 & 1.055 & 1.378 \\
\hline 26 & 0.606 & 0.000 & 0.000 & 0.606 & 0.186 & 0.792 & 1.000 & 1.307 \\
\hline 27 & 0.556 & 0.000 & 0.000 & 0.556 & 0.170 & 0.726 & 1.000 & 1.307 \\
\hline 28 & 0.381 & 0.017 & 0.000 & 0.398 & 0.122 & 0.520 & 1.046 & 1.366 \\
\hline 29 & 0.013 & 0.003 & 0.000 & 0.017 & 0.005 & 0.022 & 1.258 & 1.643 \\
\hline
\end{tabular}

Dampak Pengganda Industri Pembibitan .......... (Satria Astana, dkk.) 
Lampiran 11. Dampak Pengganda Tenaga Kerja dalam Perekonomian Desa Gerhan Golo Tahun 2004

\begin{tabular}{|c|c|c|c|c|c|c|c|c|}
\hline SECTOR & INITLAL & FIRST & INDUST & TOTAL & $C O N S^{\prime} M$ & TOTAL & TYPE I & TYPE II \\
\hline 1 & 0.000 & 0.000 & 0.000 & 0.000 & 0.000 & 0.001 & 1.738 & 2.355 \\
\hline 2 & 0.000 & 0.000 & 0.000 & 0.001 & 0.000 & 0.001 & 1.122 & 1.569 \\
\hline 3 & 0.000 & 0.000 & 0.000 & 0.000 & 0.000 & 0.000 & 1.132 & 1.583 \\
\hline 4 & 0.000 & 0.000 & 0.000 & 0.000 & 0.000 & 0.000 & 1.000 & 1.399 \\
\hline 5 & 0.000 & 0.000 & 0.000 & 0.000 & 0.000 & 0.000 & 1.000 & 1.399 \\
\hline 6 & 0.000 & 0.000 & 0.000 & 0.000 & 0.000 & 0.000 & 1.000 & 1.399 \\
\hline 7 & 0.000 & 0.000 & 0.000 & 0.000 & 0.000 & 0.000 & 0.000 & 0.000 \\
\hline 8 & 0.000 & 0.000 & 0.000 & 0.000 & 0.000 & 0.000 & 1.000 & 1.399 \\
\hline 9 & 0.000 & 0.000 & 0.000 & 0.000 & 0.000 & 0.000 & 1.182 & 1.558 \\
\hline 10 & 0.000 & 0.000 & 0.000 & 0.001 & 0.000 & 0.001 & 1.321 & 1.697 \\
\hline 11 & 0.000 & 0.000 & 0.000 & 0.000 & 0.000 & 0.000 & 1.056 & 1.554 \\
\hline 12 & 0.000 & 0.000 & 0.000 & 0.000 & 0.000 & 0.000 & 1.158 & 2.847 \\
\hline 13 & 0.000 & 0.000 & 0.000 & 0.000 & 0.000 & 0.000 & 1.321 & 2.171 \\
\hline 14 & 0.000 & 0.000 & 0.000 & 0.000 & 0.000 & 0.000 & 1.206 & 1.935 \\
\hline 15 & 0.000 & 0.000 & 0.000 & 0.000 & 0.000 & 0.000 & 1.000 & 1.540 \\
\hline 16 & 0.000 & 0.000 & 0.000 & 0.000 & 0.000 & 0.000 & 4.226 & 5.587 \\
\hline 17 & 0.000 & 0.000 & 0.000 & 0.000 & 0.000 & 0.000 & 4.049 & 6.302 \\
\hline 18 & 0.000 & 0.000 & 0.000 & 0.000 & 0.000 & 0.000 & 3.344 & 4.814 \\
\hline 19 & 0.000 & 0.000 & 0.000 & 0.000 & 0.000 & 0.000 & 1.003 & 1.455 \\
\hline 20 & 0.000 & 0.000 & 0.000 & 0.000 & 0.000 & 0.000 & 9.097 & 14.531 \\
\hline 21 & 0.000 & 0.000 & 0.000 & 0.000 & 0.000 & 0.000 & 5.538 & 7.227 \\
\hline 22 & 0.000 & 0.000 & 0.000 & 0.000 & 0.000 & 0.000 & 1.333 & 1.819 \\
\hline 23 & 0.001 & 0.000 & 0.000 & 0.001 & 0.000 & 0.001 & 1.003 & 1.042 \\
\hline 24 & 0.000 & 0.000 & 0.000 & 0.000 & 0.000 & 0.000 & 3.353 & 5.765 \\
\hline 25 & 0.000 & 0.000 & 0.000 & 0.000 & 0.000 & 0.000 & 1.014 & 1.150 \\
\hline 26 & 0.000 & 0.000 & 0.000 & 0.000 & 0.000 & 0.000 & 1.000 & 2.111 \\
\hline 27 & 0.001 & 0.000 & 0.000 & 0.001 & 0.000 & 0.001 & 1.000 & 1.185 \\
\hline 28 & 0.000 & 0.000 & 0.000 & 0.000 & 0.000 & 0.000 & 1.145 & 2.934 \\
\hline 29 & 0.000 & 0.000 & 0.000 & 0.000 & 0.000 & 0.000 & 1.436 & 1.995 \\
\hline
\end{tabular}


Lampiran 12. Keterkaitan Langsung serta Keterkaitan Langsung dan Tidak Langsung dan Dampak Penyebaran dalam Perekonomian Desa Gerhan Golo Tahun 2004

\begin{tabular}{|c|c|c|c|c|c|c|}
\hline \multirow{2}{*}{ Sektor } & \multicolumn{2}{|c|}{ Keterkaitan Langsung } & \multicolumn{2}{|c|}{$\begin{array}{l}\text { Keterkaitan Langsung dan } \\
\text { Tidak Langsung }\end{array}$} & \multicolumn{2}{|c|}{ Dampak Penyebaran } \\
\hline & Ke Depan & Ke Belakang & Ke Depan & Ke Belakang & Ke Depan & Ke Belakang \\
\hline 1 & 0.256 & 0.489 & 1.337 & 1.660 & 1.314 & 1.058 \\
\hline 2 & 0.426 & 0.141 & 1.629 & 1.184 & 0.937 & 1.290 \\
\hline 3 & 0.193 & 0.164 & 1.282 & 1.196 & 0.947 & 1.015 \\
\hline 4 & 0.000 & 0.000 & 1.000 & 1.000 & 0.792 & 0.792 \\
\hline 5 & 0.000 & 0.000 & 1.000 & 1.000 & 0.792 & 0.792 \\
\hline 6 & 0.000 & 0.000 & 1.000 & 1.000 & 0.792 & 0.792 \\
\hline 7 & 0.000 & 0.000 & 1.000 & 1.000 & 0.792 & 0.792 \\
\hline 8 & 0.621 & 0.000 & 1.621 & 1.000 & 0.792 & 1.283 \\
\hline 9 & 0.819 & 0.230 & 2.406 & 1.358 & 1.075 & 1.905 \\
\hline 10 & 0.492 & 0.323 & 1.675 & 1.365 & 1.081 & 1.326 \\
\hline 11 & 0.000 & 0.058 & 1.000 & 1.116 & 0.884 & 0.792 \\
\hline 12 & 0.198 & 0.178 & 1.224 & 1.201 & 0.951 & 0.969 \\
\hline 13 & 0.000 & 0.613 & 1.000 & 1.613 & 1.278 & 0.792 \\
\hline 14 & 0.000 & 0.141 & 1.000 & 1.280 & 1.014 & 0.792 \\
\hline 15 & 0.913 & 0.000 & 2.024 & 1.000 & 0.792 & 1.603 \\
\hline 16 & 0.345 & 0.487 & 1.429 & 1.652 & 1.309 & 1.132 \\
\hline 17 & 0.620 & 0.716 & 1.768 & 1.973 & 1.562 & 1.400 \\
\hline 18 & 0.026 & 0.069 & 1.032 & 1.094 & 0.866 & 0.817 \\
\hline 19 & 0.000 & 0.017 & 1.000 & 1.017 & 0.805 & 0.792 \\
\hline 20 & 0.099 & 0.620 & 1.239 & 2.222 & 1.760 & 0.981 \\
\hline 21 & 0.228 & 0.769 & 1.244 & 1.996 & 1.581 & 0.985 \\
\hline 22 & 0.000 & 0.083 & 1.000 & 1.100 & 0.871 & 0.792 \\
\hline 23 & 0.000 & 0.053 & 1.000 & 1.053 & 0.834 & 0.792 \\
\hline 24 & 0.078 & 0.089 & 1.108 & 1.148 & 0.909 & 0.877 \\
\hline 25 & 0.000 & 0.103 & 1.000 & 1.103 & 0.873 & 0.792 \\
\hline 26 & 0.005 & 0.000 & 1.010 & 1.000 & 0.792 & 0.800 \\
\hline 27 & 0.004 & 0.000 & 1.006 & 1.000 & 0.792 & 0.797 \\
\hline 28 & 0.000 & 0.286 & 1.000 & 1.286 & 1.018 & 0.792 \\
\hline 29 & 0.310 & 0.006 & 1.591 & 1.006 & 0.797 & 1.260 \\
\hline
\end{tabular}


Lampiran 13. Dampak Pengganda Output dalam Perekonomian Desa Gerhan Margomulyo Tahun 2004

\begin{tabular}{|c|c|c|c|c|c|c|c|c|}
\hline SECTOR & INITIAL & FIRST & INDUST & TOTAL & CONS'M & TOTAL & TYPE I & TYPE II \\
\hline 1 & 1.000 & 0.354 & 0.189 & 1.543 & 0.038 & 1.582 & 1.543 & 1.582 \\
2 & 1.000 & 0.475 & 0.165 & 1.639 & 0.593 & 2.233 & 1.639 & 2.233 \\
3 & 1.000 & 0.176 & 0.010 & 1.186 & 0.298 & 1.484 & 1.186 & 1.484 \\
4 & 1.000 & 0.122 & 0.017 & 1.139 & 0.080 & 1.219 & 1.139 & 1.219 \\
5 & 1.000 & 0.054 & 0.000 & 1.054 & 0.376 & 1.430 & 1.054 & 1.430 \\
6 & 1.000 & 0.062 & 0.006 & 1.068 & 0.298 & 1.366 & 1.068 & 1.366 \\
7 & 1.000 & 0.023 & 0.000 & 1.023 & 0.182 & 1.205 & 1.023 & 1.205 \\
$\mathbf{8}$ & $\mathbf{1 . 0 0 0}$ & $\mathbf{0 . 0 0 0}$ & $\mathbf{0 . 0 0 0}$ & $\mathbf{1 . 0 0 0}$ & $\mathbf{0 . 5 4 1}$ & $\mathbf{1 . 5 4 1}$ & $\mathbf{1 . 0 0 0}$ & $\mathbf{1 . 5 4 1}$ \\
9 & 1.000 & 0.101 & 0.010 & 1.111 & 0.052 & 1.163 & 1.111 & 1.163 \\
$\mathbf{1 0}$ & $\mathbf{1 . 0 0 0}$ & $\mathbf{0 . 0 0 1}$ & $\mathbf{0 . 0 0 0}$ & $\mathbf{1 . 0 0 1}$ & $\mathbf{0 . 0 2 2}$ & $\mathbf{1 . 0 2 3}$ & $\mathbf{1 . 0 0 1}$ & $\mathbf{1 . 0 2 3}$ \\
$\mathbf{1 1}$ & $\mathbf{1 . 0 0 0}$ & $\mathbf{0 . 3 3 4}$ & $\mathbf{0 . 0 0 0}$ & $\mathbf{1 . 3 3 4}$ & $\mathbf{0 . 3 7 7}$ & $\mathbf{1 . 7 1 1}$ & $\mathbf{1 . 3 3 4}$ & $\mathbf{1 . 7 1 1}$ \\
12 & 1.000 & 0.233 & 0.000 & 1.233 & 0.860 & 2.092 & 1.233 & 2.092 \\
13 & 1.000 & 0.000 & 0.000 & 1.000 & 0.154 & 1.154 & 1.000 & 1.154 \\
14 & 1.000 & 0.020 & 0.000 & 1.020 & 0.010 & 1.030 & 1.020 & 1.030 \\
15 & 1.000 & 0.162 & 0.009 & 1.171 & 0.069 & 1.240 & 1.171 & 1.240 \\
16 & 1.000 & 0.186 & 0.020 & 1.207 & 0.229 & 1.435 & 1.207 & 1.435 \\
17 & 1.000 & 0.313 & 0.000 & 1.313 & 0.073 & 1.387 & 1.313 & 1.387 \\
18 & 1.000 & 0.000 & 0.000 & 1.000 & 0.661 & 1.661 & 1.000 & 1.661 \\
19 & 1.000 & 0.000 & 0.000 & 1.000 & 0.091 & 1.091 & 1.000 & 1.091 \\
20 & 1.000 & 0.043 & 0.000 & 1.043 & 0.239 & 1.282 & 1.043 & 1.282 \\
21 & 1.000 & 0.000 & 0.000 & 1.000 & 0.324 & 1.324 & 1.000 & 1.324 \\
22 & 1.000 & 0.000 & 0.000 & 1.000 & 0.351 & 1.351 & 1.000 & 1.351 \\
\hline
\end{tabular}


Lampiran 14. Dampak Pengganda Pendapatan dalam Perekonomian Desa Gerhan Margomulyo Tahun 2004

\begin{tabular}{|c|c|c|c|c|c|c|c|c|}
\hline SECTOR & INITLAL & FIRST & INDUST & TOTAL & CONS'M & TOTAL & TYPE I & TYPE II \\
\hline 1 & 0.017 & 0.007 & 0.003 & 0.027 & 0.005 & 0.031 & 1.599 & 1.871 \\
2 & 0.279 & 0.099 & 0.034 & 0.412 & 0.070 & 0.482 & 1.474 & 1.725 \\
3 & 0.180 & 0.025 & 0.001 & 0.207 & 0.035 & 0.242 & 1.147 & 1.342 \\
4 & 0.049 & 0.006 & 0.001 & 0.056 & 0.009 & 0.065 & 1.139 & 1.333 \\
5 & 0.255 & 0.006 & 0.000 & 0.261 & 0.044 & 0.306 & 1.022 & 1.196 \\
6 & 0.199 & 0.007 & 0.001 & 0.207 & 0.035 & 0.242 & 1.039 & 1.216 \\
7 & 0.123 & 0.004 & 0.000 & 0.126 & 0.021 & 0.148 & 1.031 & 1.206 \\
$\mathbf{8}$ & $\mathbf{0 . 3 7 5}$ & $\mathbf{0 . 0 0 0}$ & $\mathbf{0 . 0 0 0}$ & $\mathbf{0 . 3 7 5}$ & $\mathbf{0 . 0 6 4}$ & $\mathbf{0 . 4 3 9}$ & $\mathbf{1 . 0 0 0}$ & $\mathbf{1 . 1 7 0}$ \\
9 & 0.014 & 0.021 & 0.001 & 0.036 & 0.006 & 0.042 & 2.640 & 3.090 \\
$\mathbf{1 0}$ & $\mathbf{0 . 0 1 5}$ & $\mathbf{0 . 0 0 0}$ & $\mathbf{0 . 0 0 0}$ & $\mathbf{0 . 0 1 5}$ & $\mathbf{0 . 0 0 3}$ & $\mathbf{0 . 0 1 8}$ & $\mathbf{1 . 0 1 5}$ & $\mathbf{1 . 1 8 8}$ \\
$\mathbf{1 1}$ & $\mathbf{0 . 2 0 5}$ & $\mathbf{0 . 0 5 7}$ & $\mathbf{0 . 0 0 0}$ & $\mathbf{0 . 2 6 1}$ & $\mathbf{0 . 0 4 4}$ & $\mathbf{0 . 3 0 6}$ & $\mathbf{1 . 2 7 8}$ & $\mathbf{1 . 4 9 6}$ \\
12 & 0.571 & 0.025 & 0.000 & 0.596 & 0.101 & 0.698 & 1.043 & 1.221 \\
13 & 0.107 & 0.000 & 0.000 & 0.107 & 0.018 & 0.125 & 1.000 & 1.170 \\
14 & 0.004 & 0.002 & 0.000 & 0.007 & 0.001 & 0.008 & 1.583 & 1.852 \\
15 & 0.020 & 0.026 & 0.001 & 0.048 & 0.008 & 0.056 & 2.358 & 2.760 \\
16 & 0.141 & 0.015 & 0.003 & 0.159 & 0.027 & 0.186 & 1.127 & 1.319 \\
17 & 0.031 & 0.020 & 0.000 & 0.051 & 0.009 & 0.060 & 1.635 & 1.913 \\
18 & 0.458 & 0.000 & 0.000 & 0.458 & 0.078 & 0.536 & 1.000 & 1.170 \\
19 & 0.063 & 0.000 & 0.000 & 0.063 & 0.011 & 0.074 & 1.000 & 1.170 \\
20 & 0.155 & 0.010 & 0.000 & 0.166 & 0.028 & 0.194 & 1.068 & 1.249 \\
21 & 0.225 & 0.000 & 0.000 & 0.225 & 0.038 & 0.263 & 1.000 & 1.170 \\
22 & 0.243 & 0.000 & 0.000 & 0.243 & 0.041 & 0.285 & 1.000 & 1.170 \\
\hline
\end{tabular}

Dampak Pengganda Industri Pembibitan .......... (Satria Astana, dkk.) 
Lampiran 15. Dampak Pengganda Tenaga Kerja dalam Perekonomian Desa Gerhan Margomulyo Tahun 2004

\begin{tabular}{|c|c|c|c|c|c|c|c|c|}
\hline SECTOR & INITLAL & FIRST & INDUST & TOTAL & CONS'M & TOTAL & TYPE I & TYPE II \\
\hline 1 & 0.000 & 0.000 & 0.000 & 0.000 & 0.000 & 0.000 & 1.604 & 2.015 \\
2 & 0.000 & 0.000 & 0.000 & 0.000 & 0.000 & 0.000 & 1.408 & 1.597 \\
3 & 0.000 & 0.000 & 0.000 & 0.000 & 0.000 & 0.000 & 1.068 & 1.142 \\
4 & 0.000 & 0.000 & 0.000 & 0.000 & 0.000 & 0.000 & 1.139 & 1.189 \\
5 & 0.003 & 0.000 & 0.000 & 0.003 & 0.000 & 0.003 & 1.001 & 1.012 \\
6 & 0.000 & 0.000 & 0.000 & 0.000 & 0.000 & 0.000 & 1.043 & 1.314 \\
7 & 0.000 & 0.000 & 0.000 & 0.000 & 0.000 & 0.000 & 1.031 & 1.296 \\
$\mathbf{8}$ & $\mathbf{0 . 0 0 4}$ & $\mathbf{0 . 0 0 0}$ & $\mathbf{0 . 0 0 0}$ & $\mathbf{0 . 0 0 4}$ & $\mathbf{0 . 0 0 0}$ & $\mathbf{0 . 0 0 4}$ & $\mathbf{1 . 0 0 0}$ & $\mathbf{1 . 0 1 0}$ \\
9 & 0.000 & 0.000 & 0.000 & 0.000 & 0.000 & 0.000 & 2.494 & 2.755 \\
$\mathbf{1 0}$ & $\mathbf{0 . 0 0 0}$ & $\mathbf{0 . 0 0 0}$ & $\mathbf{0 . 0 0 0}$ & $\mathbf{0 . 0 0 0}$ & $\mathbf{0 . 0 0 0}$ & $\mathbf{0 . 0 0 0}$ & $\mathbf{1 . 0 2 1}$ & $\mathbf{1 . 3 9 5}$ \\
$\mathbf{1 1}$ & $\mathbf{0 . 0 0 0}$ & $\mathbf{0 . 0 0 0}$ & $\mathbf{0 . 0 0 0}$ & $\mathbf{0 . 0 0 0}$ & $\mathbf{0 . 0 0 0}$ & $\mathbf{0 . 0 0 0}$ & $\mathbf{1 . 2 8 2}$ & $\mathbf{1 . 6 1 5}$ \\
12 & 0.000 & 0.000 & 0.000 & 0.000 & 0.000 & 0.000 & 1.060 & 1.404 \\
13 & 0.000 & 0.000 & 0.000 & 0.000 & 0.000 & 0.000 & 1.000 & 1.237 \\
14 & 0.000 & 0.000 & 0.000 & 0.000 & 0.000 & 0.000 & 1.324 & 1.549 \\
15 & 0.000 & 0.000 & 0.000 & 0.000 & 0.000 & 0.000 & 1.742 & 2.078 \\
16 & 0.000 & 0.000 & 0.000 & 0.000 & 0.000 & 0.000 & 1.866 & 2.163 \\
17 & 0.000 & 0.000 & 0.000 & 0.000 & 0.000 & 0.000 & 1.952 & 2.275 \\
18 & 0.000 & 0.000 & 0.000 & 0.000 & 0.000 & 0.000 & 1.000 & 1.226 \\
19 & 0.000 & 0.000 & 0.000 & 0.000 & 0.000 & 0.000 & 1.000 & 1.132 \\
20 & 0.000 & 0.000 & 0.000 & 0.000 & 0.000 & 0.000 & 1.065 & 1.329 \\
21 & 0.000 & 0.000 & 0.000 & 0.000 & 0.000 & 0.000 & 1.000 & 1.296 \\
22 & 0.000 & 0.000 & 0.000 & 0.000 & 0.000 & 0.000 & 1.000 & 1.256 \\
\hline
\end{tabular}


Lampiran 16. Keterkaitan Langsung serta Keterkaitan Langsung dan Tidak Langsung dan Dampak Penyebaran dalam Perekonomian Desa Gerhan Margomulyo Tahun 2004

\begin{tabular}{|c|c|c|c|c|c|c|}
\hline \multirow{2}{*}{ Sektor } & \multicolumn{2}{|c|}{ Keterkaitan Langsung } & \multicolumn{2}{|c|}{$\begin{array}{c}\text { Keterkaitan Langsung dan } \\
\text { Tidak Langsung }\end{array}$} & \multicolumn{2}{|c|}{ Dampak Penyebaran } \\
\hline & Ke Depan & Ke Belakang & Ke Depan & Ke Belakang & Ke Depan & $\mathrm{Ke} \mathrm{Be}_{\text {lakang }}$ \\
\hline 1 & 0.348 & 0.354 & 1.533 & 1.543 & 1.345 & 1.354 \\
\hline 2 & 0.251 & 0.475 & 1.336 & 1.639 & 1.171 & 1.438 \\
\hline 3 & 0.094 & 0.176 & 1.104 & 1.186 & 0.968 & 1.040 \\
\hline 4 & 0.122 & 0.122 & 1.139 & 1.139 & 0.999 & 0.999 \\
\hline 5 & 0.016 & 0.054 & 1.016 & 1.054 & 0.891 & 0.924 \\
\hline 6 & 0.206 & 0.062 & 1.229 & 1.068 & 1.078 & 0.937 \\
\hline 7 & 0.095 & 0.023 & 1.113 & 1.023 & 0.976 & 0.897 \\
\hline 8 & 0.000 & 0.000 & 1.000 & 1.000 & 0.877 & 0.877 \\
\hline 9 & 0.113 & 0.101 & 1.113 & 1.111 & 0.976 & 0.974 \\
\hline 10 & 0.137 & 0.001 & 1.139 & 1.001 & 0.999 & 0.878 \\
\hline 11 & 0.000 & 0.334 & 1.000 & 1.334 & 0.877 & 1.170 \\
\hline 12 & 0.000 & 0.233 & 1.000 & 1.233 & 0.877 & 1.081 \\
\hline 13 & 0.505 & 0.000 & 1.563 & 1.000 & 1.371 & 0.877 \\
\hline 14 & 0.008 & 0.020 & 1.009 & 1.020 & 0.884 & 0.895 \\
\hline 15 & 0.037 & 0.162 & 1.046 & 1.171 & 0.917 & 1.027 \\
\hline 16 & 0.000 & 0.186 & 1.000 & 1.207 & 0.877 & 1.058 \\
\hline 17 & 0.023 & 0.313 & 1.023 & 1.313 & 0.897 & 1.152 \\
\hline 18 & 0.000 & 0.000 & 1.000 & 1.000 & 0.877 & 0.877 \\
\hline 19 & 0.313 & 0.000 & 1.320 & 1.000 & 1.158 & 0.877 \\
\hline 20 & 0.000 & 0.043 & 1.000 & 1.043 & 0.877 & 0.915 \\
\hline 21 & 0.000 & 0.000 & 1.000 & 1.000 & 0.877 & 0.877 \\
\hline 22 & 0.392 & 0.000 & 1.404 & 1.000 & 1.231 & 0.877 \\
\hline
\end{tabular}

